\title{
İlçelerin Yerel Kalkınmasında Sanayi ve Ticaret Odalarının Rolü: Torbalı Ticaret Odası Örneği
}

The Role of Chambers of Industry and Commerce in the Local Development of Districts: The Case of Torball Chamber of Commerce

\section{Vedat YILMAZ}

Dr. Öğr. Üyesi, Van Yüzüncü Yll Üniversitesi,

IİBF, Кати Yönetimi Bölümü,

vedatyilmaz1977@gmail.com

https://orcid.org/0000-0003-4624-9824

\section{Nur ÇELİK EFŞAN}

Yüksek Lisans Öğr., Van Yüzüncü Yll Üniversitesi,

SBE, Кати Yönetimi A.B.D.,

ncelikefsan@gmail.com

https://orcid.org/0000-0002-8210-3139
Makale Başvuru Tarihi: 23.08.2019

Makale Kabul Tarihi: 10.08.2019

Makale Türü: Araştırma Makalesi

\begin{abstract}
Anahtar
Kelimeler:

Dış Ticaret,

Kent,

Yerel Ekonomik

Kalkınma,

Torbalı Ticaret

Odasi,

M.Ö. 12.yüzylldan günümüze kadar ticaret, ülkeler arasında ekonomik ilişkilerin en önemli unsuru olarak görülmektedir. Ticaret, 12.ve 13. yüzylllarda Orta Çă̆'da aristokrasi ve burjuvazi arasında çıan çatışmaların sonucunda burjuva sınıfinın kentlerde yoğunlaşması ve endüstrileşmeyi başlatması ile önem kazanmıştır. Kentlerde önceleri küçük esnaf birlikleri olarak başlayan ticari hayat, coğrafi keşiflerle birlikte sömürgeleşmenin artmasıyla ülkeler arası maden rezervlerinin oluştuğu ve dış ticarete eğilimin arttı̆̆ merkantilist dönemde ticari faaliyetlerin yürütülmesi noktasında daha organize kuruluşlara ihtiyaç bırakmıştır. 16. yüzyılın sonlarında sistematik hale gelen ticaret odalarl, 20. yüzyılda ortaya çıkan yerelleşme akımının etkisiyle iyi yönetişim yaklaşımının önemli paydaşları arasına girmiştir. Bu çalışmada yerel ekonomik kalkınma yaklaşımı ekseninde Torbalı Ticaret Odası'nın yürüttüğ̈̈ faaliyetler ve ilçe ekonomisine katkıları incelenmiştir. Araştırmanın yapılmasında odanın ilçe ekonomisi ve ilçe sorunlarının çözümüne ilişkin katkılarını ortaya çıkarmak amacıyla oda yetkililerine; ilçenin tanıtımına, ilçe kanaat önderliği ve meclisteki yasama sürecine, işsizlikle mücadeleye ve yurt içi ve yurt dişındaki ticaret odaları ve fuarcllık hizmetlerine yönelik faaliyetleri konusunda sorular yöneltilmiştir.
\end{abstract}

Keywords:

Foreigntrade,

City,

Local Economic

Development,

Torball Chamber of Commerce,

\section{ÖZET}

\section{ABSTRACT}

Trade is seen as the most important element of economic relations between countries from the $12^{\text {th }}$ century $B C$. to the present day. Trade gained importance in the $12^{\text {th }}$ And $13^{\text {th }}$ century as a result of the conflicts between the aristocracy and the bourgeoisie in the Middle Ages, when the bourgeois class intensified to the cities and started industrialization in the cities. Commercial life which started as small trades unions in the cities has left the need for more organized organizations with the formation of mineral reserves between countries with the increase of colonization with geographical discoveries and to carry out commercial activities in the mercantile period where the trend towards foreign trade has increased.The chambers of commerce, which became systematic in the late $16^{\text {th }}$ century, became one of the important stakeholders of the good governance approach due to the localization movement that emerged in the $20^{\text {th }}$ century. In this study, the activities carried out by Torball Chamber of Commerce on the basis of local economic development approach and their contributions to the county economy were examined. In order to reveal the chamber's contributions to the solution of district economy and district problems in the conduct of the research, questions were raised to the chamber authorities about the promotion of the district, the district opinion leadership and the legislative process in the assembly, the fight against unemployment and its activities for domestic and international chambers of commerce and fair services. 


\section{GIRISS}

Yerel kalkınma, ülke genelinde kalkınma sürecini başarıya ulaştıran önemli bir kilit taşıdır. Yerel kaynakların etkin kullanımı sorununun ortaya çıkması ve yereldeki ekonomik, sosyal ve fiziki gelişmelerin kentlerin geleceği konusundaki belirleyiciliğinin artmasıyla birlikte yerel kalkınma kavramının önemi artış göstermiştir. Ulusal kalkınmanın gerçekleştirilmesinde temel unsur olan yerel kalkınmanın yerel kaynakları daha etkin ve verimli bir şekilde kullanılmasıyla sağlanacağı düşüncesinden hareket edilerek yerelde yer alan belediye, kaymakamlık, üniversiteler, diğer kamu kurumları ve sivil toplum kuruluşlarının koordineli bir şekilde çalışması önem arz etmektedir.

İlçelerin kalkınmasında ticaret odalarının önemli bir yeri bulunmaktadır. Bu doğrultuda bu araştırmada Türkiye'de bulunan ticaret odalarının ilçelerin kalkınmasındaki rolü ele alınacaktır. Çalışmanın amacı; Türkiye'de bulunan ilçelerdeki ticaret odalarının yerel kalkınmadaki faaliyetlerinin gündeme taşınmasıdır. Bu bağlamda araştırmada örneklem olarak İzmir'in, aynı zamanda Türkiye'nin lokomotifi konumunda bir kent olan Torbalı ilçesinde bulunan Torbalı Ticaret Odası alınmışıtır. 13-14 Haziran 2019 tarihleri arasında Torbalı Ticaret Odası yetkilileri (Ticaret Odası Başkanı, Dış Ticaret Uzmanı, KOSGEB Temsilcisi ve Ege İhracatçı Birlikleri Basın Müşaviri) ile yüz yüze görüşülmüştür. Yol ve maliyet gibi unsurlar dikkate alınarak çalışma bir ilçe ile sınırlandırılmıştır. Çalışmada nitel araştırma türlerinden mülakat ve gözlem yöntemi kullanılarak Torbalı Tícaret Odası'nın ilçenin kalkınmasındaki faaliyetleri ve katkısı hakkında 17 sorudan oluşan görüşme formu çerçevesinde bilgiler toplanmıştır. Toplanan bilgiler doğrultusunda çalışmada; Türkiye ve dünyadaki sanayi ve ticaret odalarının tarihsel gelişimi, yerel kalkınma yaklaşımı, ticaret odalarının yerel kalkınmadaki rolüne ilişkin görüşler, Türkiye'de sanayi ve ticaret odalarının gelişimi ve fonksiyonu ile Torbalı Ticaret Odası'nın oda üyelerine yönelik faaliyetleri, odanın ilçe tanıtımına yönelik faaliyetleri, işsizlikle mücadeleye yönelik faaliyetleri, yurt dışındaki ticaret odaları ve fuarcılık hizmetlerine yönelik faaliyetleri, ilçe kanaat önderliğine yönelik faaliyetleri, mecliste yasama sürecine yönelik faaliyetleri incelenmiş ve analiz edilerek, Torbalı Ticaret Odası'nın ilçe ekonomik göstergelerine katkısı hakkında bilgiler sunulmuştur.

\section{TÜRKIYYE'DE VE DÜNYADA SANAYİ VE TICCARET ODALARININ TARİHSEL GELİSiMII}

Dünya'da ticaret tarih öncesi dönemden başlayıp günümüze kadar çeşitli düzeylerde gelişim göstermiştir. İlk kez M.Ö. 12.yy'da Tunus ve Akdeniz kıyılarında hâkimiyet gösteren Fenike Uygarlığı deniz ticaretine yönelmiş, deniz kıyılarında fethettikleri bölgeleri kendilerine bağlayarak buralardan aldıkları ürünleri başka ülkelere satarak ticari faaliyetlerde bulunmuşlardır. Bu dönemde Mezopotamya'da ise Sümer, Babil, Misır uygarlıkları ticari faaliyetlerde bulunmaktaydılar. Avrupa'da 12. ve 13. yy'larda tarımla ekonomik faaliyetlerin başlamasının akabinde Orta Çağ'ın sonlarında feodal düzende senyörler ve kilise ile mücadele eden sosyal sınıfin bu mücadeleden kaçış çabaları kırdan kente göçle sonuçlanmış olup, göç edilen kentlerde ticari faaliyetlerin başlamasına ön ayak olmuşlardır. Orta Çăg'ın sonlarında aristokrasiye karşı burjuva sınıfı Sanayi Devrimi'ni gerçekleştirerek parlamentoda da söz hakkına sahip olmuş, siyasi haklarını kazanmış güçlü ticari örgütlerin kurucusu olmuştur. Bu dönemden itibaren dünyada ticari ortaklıklar kurulmaya başlanmış ve ticari ortaklık şeklinde kurulan ilk örgütlenme 12.yy'da ortaya çıkmış, 13. yy'da ise tüm Avrupa'ya yayılmıştır. Bu dönemde Orta Çağ'daki üretim sistemi lonca denen küçük esnaf birlikleri eliyle yürütülmüştür. Zamanla kent nüfusunun göçler yoluyla artması ile loncalar yeterli gelmemeye başlamış, burjuvazi daha büyük örgütler kurarak üretim ve ticaret yapmaya başlamıştır. Dönem içinde coğrafi keşifler artmış ve keşifler sonunda sömürge haline getirilen ülkelerden elde edilen maden rezervleri başta İngiltere olmak üzere Almanya, Belçika, Hollanda, Fransa, Portekiz ve İspanya gibi ülkelerin hazinelerindeki maden stokunu arttırmış ve artan stoklar dünyada farklı ülkelere satılarak dış ticaret faaliyetleri yürütülmüştür. Mamul mal alımının yasak, ham madde alımının serbest olduğu 15. ve 17. yy'ları kapsayan bu yeni dönem merkantilist dönem olarak adlandırılmış ve ticari faaliyetler örgütlü olarak yürütülmeye başlanmıştır (Aydemir ve Güneş, 2006: 136).

Dünyada dış ticaretin yapılmaya başlanmasıyla ülkeler arası ticari ilişkilerin yürütülmesini organize eden ticaret odaları kurulmaya başlanmıştır. Dünyada ticaret odası olarak ilk kurulan örgüt 1600'de Fransa'da kurulan Marsilya Ticaret Odası'dır. Bunu 1768'te Kuzey Amerika'da New York'ta kurulan ticaret odası takip etmiş, son olarak 1804'te Kanada'da Halifax'ta kurulmuştur. Türkiye'de ise ticari örgütlenmeye ilişkin modern uygulamalara daha geç başlandığı gözlemlenmektedir. Osmanlı döneminde sadece Müslüman esnafin kayıt olabildiği, mesleki ahlakı ve düzeni sağlayan, ürün kalitesini, vatandaşın hizmet memnuniyetini ve vatandaş esnaf ilişkisini düzenleyen loncalar, artan fetihlerle gayrimüslim esnafın sayıca artışıla birlikte yerini gedik adı verilen esnaf örgütlenmelerine bırakmıştır. Türkiye'de Avrupa tarzı ticaret ve sanayi odalarının kuruluş süreci 
ise ilk kez 1867 'de Isparta Ticaret ve Sanayi Odası'nın kurulmasıyla başlamış olup bunu 1874'te Trabzon, 1879 'da Tarsus'ta kurulan odalar takip etmiştir. Son olarak borsalar yönünden ticari düzeni sağlayan Umumi Borsalar Nizamnamesi'nin yürürlüğe girmesiyle 1891 'de "İzmir Ticaret ve Sanayi Borsasl" kurulmuştur.1950'de kabul edilen 8 Mart 1950 tarihli 5590 sayıl kanunla birlikte ticaret ve sanayi odaları özerklik kazanmıştır. 1988'de ilgili kanunda bazı maddelerin değiştirilmesi yönünde düzenlemeler yapılmıştır.

Ülkemizde 2004'e kadar ticaret ve sanayi odalarıyla ilgili bir kanun düzenlemesi yapılmamış olup ticaret ve sanayi odaları ile borsaların çatı kuruluşu olan Türkiye Odalar ve Borsalar Birliği 18 Mayıs 2004 tarihli 5174 sayılı Türkiye Odalar ve Borsalar Birliği ile Odalar ve Borsalar Kanunu ile düzenlenmiştir. TOBB şemsiyesi altında; 160 ilçede 181 Ticaret ve Sanayi Odası, 57 Ticaret Odası, 12 Sanayi Odası, 2 Deniz Ticaret Odası, 113 Ticaret Borsası olmak üzere 365 kuruluş bulunmakta ve 1,5 milyon üye ile hizmet vermektedir. Odaların kuruluş amacı üyelerinin ortak ihtiyaçlarını karşılayarak mesleki faaliyetlerini kolaylaştırmak, mesleklerin gelişmesini sağlayarak meslek mensuplarının birbiriyle ve halkla entegrasyonunu sağlamak amacıyla mesleki ahlak ve disiplini temin etmektir. Oda ve borsalar meslek komiteleri, meclis, yönetim kurulu ve disiplin kurulu organları ile hizmet vermektedirler (TOBB Faaliyet Raporu, 2017:3-4).

\section{YEREL KALKINMA YAKLAȘIMINA GENEL BAKIS}

Dünyada 1980'lere kadar geleneksel kalkınma modeli hâkimken, 80'lerden sonra merkezden yönetilen ve yerel idarenin ekarte edildiği yönetim tarzının önce yerel daha sonra ulusal kalkınmayı olumsuz etkilediği tespit edilmiştir. Bunun sonucu olarak 80'lerden sonra yerelin etkin ve verimli yönetiminde ve yerel kaynakların değerlendirilmesinde iyi yönetişim perspektifinde merkezden yerele doğru yetki devirlerinin artması ile geleneksel kalkınma modeli terk edilerek yerel ekonomik kalkınma yaklaşımı ortaya çıkmıştır (Deviren ve Yildiz, 2014:29).

Geleneksel kalkınma modelinde mevcut yerel kaynaklar tespit edilmeden yerel kaynakların etkin kullanımına ilişkin yöntemler geliştirilmeden tepeden inme alınan kararlarla kalkınma planları oluşturulmuş ve bu planların yereldeki aktörlere uygulatılması beklenmiştir.Yerel inisiyatifin göz önünde bulundurulmadığı bu yaklaşım uzun vadede başarı gösterememiştir.Hâlbuki yerel ekonomik kalkınma yaklaşımında yerel ile ilgili her türlü değişimin yerelde yapılması, yerel yönetimlerin güçlendirilerek merkezi yönetime duyduğu ihtiyacı azaltmaktadır.Yani bu süreçte yereldeki aktörler kendi öz kaynaklarını oluşturarak yerel kalkınmaya katkıda bulunmaktadır.

Geleneksel kalkınma modelinde; yerel ile ilgili kararlar merkezden alınırken, yönetim merkezi idare tarafindan sağlanmaktadır. Yerel kalkınmada sektörel yaklaşım geçerli iken ekonomik faaliyetler için büyük endüstriyel projeler geliştirilmektedir. Ekonomik faaliyetleri çekebilmek için devlet yardımları etkili olmuştur.Yerel ekonomik kalkınma modelinde ise kalkınma yerel inisiyatifin eliyle gerçekleştirilmektedir. Kalkınma planı sadece devlet eliyle değil kamu-özel sektör ortaklığı ile yatay bir yapı içerisinde yürütülmektedir. Kalkınmada büyük endüstriyel projeler yerine yerelleşme, çevre gibi alansal yaklaşımlar geçerlidir. Ayrıca yerel ekonomik sistemle değişen çevre arasında uyum dikkate alınmakta, geleneksel modelde olduğu gibi sektörel yaklaşım baz alınmamaktadır, yani sürdürülebilir ekonomik kalkınmanın sağlanmasında çevre endeksli üretim süreci önem taşımakta; bunun gerçekleştirilmesinde ise hükümete görevler düşmektedir (Rodriguez-Pose, 2001'den akt.: Çetin, 2007:157).

19. yüzy1lda bilgi ve teknolojideki ilerlemelere paralel olarak endüstriyel üretim gelişmiş, bunun sonucunda ülkeler arasında ekonomik gelişmişlik farkları ortaya çıkmıştır. Bu farklar 20.yüzyılda endüstriyel üretimin artışıyla birlikte küreselleşmeye ortam hazırlamış, ülkeler arasında rekabet hız kazanmıştır. Küresel rekabetin sonucu olarak ülkeler arasındaki yarışta ülkelerin gelişmişlik farkları ortaya çıkmış, hatta aynı ülkede bölgeler arasında gelişim farklarının olduğu bir döneme girilmiştir. Ülkelerin aynı oranda eş zamanlı sanayileşememesinin sonucu olarak ulusal kalkınma hedefinde bölgesel kalkınma politikalarının üretilmesi zorunlu hale gelmiştir (Şanl1, 2004: 160-161).

Küreselleşen dünyada küreselleşmenin tersi olarak yerelleşme hız kazanmıştır.Küreselleşmenin başarıya ulaşması yereldeki başarıya bağlandığı için küreselleşme ile yerelleşme aynı paralelde ilerleme kaydetmiştir.Günümüzde küresel firmaların ticaret hacimlerini geliştirmek için yerel politikaları referans aldığı görülmektedir.Dünyaca ünlü markalar her ülkenin mevcut sosyo-ekonomik durumuna göre yerel üretim politikaları geliştirmekte, bu politikaları yereldeki kuruluşlarına benimseterek uygulatmakta ve küresel ölçekte toplam kazancını arttırmaktadır. Demek ki küreselleşme ile yerelleşme aslında zıt kavramlar değil, tamamlayıcı kavramlardır. Buradan hareketle dünyada ulusal yönetimlerdeki başarı yereldeki başarı ile doğru orantılı olarak 
sağlanmaktadır denebilir. Yani yerelde ekonomik kalkınmayı oluşturan parametreler zincirleme olarak ulusal ekonomik kalkınmayı doğrudan etkilemektedir. Bu nedenle kalkınma yerelden başlamaktadır.

Günümüzde endüstriyel üretimin kentlerde yoğunlaşması ve kırdan kente yapılan göçlerin etkisiyle birlikte kentlerde nüfus artmış, buna bağlı olarak kentsel rekabet ve işgücü açı̆̆g artmıştır.Kentlerin nüfusun çekim merkezi olması yönüyle kentler arası rekabet artmış, kentler arası yarışlar yerel kaynakların planlanması ve verimli bir şekilde kullanılması sorununu ortaya çıkarmıştır.Yerel kaynakların değerlendirilmesi konusu ise yerel ekonomik kalkınma kavramına ortam hazırlamıştır (Kaya, 2001:28).Ülkelerin ekonomik kalkınmasının sağlanması için her bölgenin öz yerel kaynaklarının farklı olması ve bölgelerin mevcut durumlarının birbirlerinden farklılık göstermesi ülke içinde farklı yerel kalkınma politikalarının belirlenmesine neden olmuştur.

Yerel ekonomik kalkınmanın gerçekleştirilmesinde kentin ve toplumun mevcut durumu analiz edilmelidir. Var olan firsat ve tehditler belirlenerek içsel ve dışsal potansiyel tespit edilmelidir. Kamu ve özel sektör işbirlikleri yapılarak yerel ajanlar koordineli çalışmalıdır. Bir yerel sorunun çözümünde çözüme ilişkin tüm paydaşlar görev paylaşımı yapmalı, yerel inisiyatif oluşturulmalıdır. Yerel ekonomik kalkınmanın gerçekleştirilmesi ve sürdürülebilir hale gelmesinde beşeri sermaye ve çevre faktörleri önemli bir yere sahiptir. Çünkü artan ekonomik göstergeler ekonomik büyümeyi sağlayabilir, ancak yerel ekonomik kalkınmanın sağlanması beşeri sermayenin iyi değerlendirilmesi ve çevreyi koruyucu üretimin yapılması ile mümkün olmakta, sürekli hale gelmektedir.Bu anlamda ekonomik olan veya olmayan faktörler yerel kalkınma sürecini etkilemektedir.Sivil toplum kuruluşları, yerel yönetimler, özel firmalar ve işçiler bu sürece katkıda bulunmaktadır.Devlet yerel ekonomik kalkınmanın bir koordinatörü olarak yereldeki kalkınmaya ilişkin geliştirilen politikaları üreten yerel politikacılarla sıkı ilişkiler içinde olmalıdır.Yerel ekonomik kalkınmanın yürütülmesinde politika yapıcıları yerel alternatifleri gerçekçi olarak yönettiği takdirde başarıya ulaşacaklardır (Leigh ve Blakely, 2017:63).Yerel kalkınma yaklaşımında ana prensip, yerel toplulukların ekonomik, sosyal ve siyasi olarak harekete geçirilerek kalkınma sürecine dâhil edilmesi olmalıdır.

Helmsing'e (2005:66-67) göre yerel halk; işçi, tüketici ve girişimci üçgeninde tanımlanmaktadır.Yerel ekonomik kalkınmanın en önemli unsuru olan yapısal düzenlemeler piyasa işleyişi konusunda merkezden yerel yönetimlere yetki devri yapılmasını ifade etmektedir.Çünkü personel, sermaye ve üretici firma gibi üretim faktörlerinden yoksun olan yerel yönetimler özel sektöre göre dezavantajlı konumdadır.Bu nedenle yerel yönetimler tek başına yerel kalkınmayı sağlayabilecek durumda değildir.Bunun sağlanması kamu-özel sektör ortaklıklarının yapılmasına bağlıdır.Burada beşeri sermayenin rolü tartışmasız çok önemlidir.Çünkü yerel ekonomik kalkınmaya giden yolda yerel halkın mikro girişimci programlarıyla tanıştırılarak, girişimcilik konusunda eğitim ve kredi desteği verilmesi yoluyla yerelde üretim ve istihdam artacaktır (Gürler Hazman, 2011:21-22).

Değişen ve dönüşen zaman içerisinde dikkate değer bir gelişim gösteren yerel ekonomik kalkınma, yerel yönetimlerin etkinliğinin ve verimliliğinin artırılması noktasında önemli düzeyde katkı sağlamakla (Atmaca, 2018:428) birlikte ulusal kalkınma planlarının hazırlanmasında ve ulusal ekonomik gelişmişliğin ortaya konmasında bir kilit taşı olarak yerel inisiyatifin harekete geçirilmesi için yardımcı olmaktadır. Ayrıca yerel ve ulusal düzlemde ekonomik kalkınmanın gerçekleştirilmesinde bölgelerin ekonomik gelişmişlik düzeyini ortaya koyarak kalkınmaya ihtiyaç duyulan bölgelere doğru merkezden yerele kaynak aktarımının yapılması, gelişmemiş veya gelişmekte olan bölgelere yatırım destekleri verilmesi ile ulusal kalkınma planındaki önceliklerin belirlenmesi konularında önem taşımaktadır.

Yerel kalkınma hamlelerinin yapılması güçlü finans kaynaklarına sahip olmayı gerektirebilmektedir.Bu nedenle yerel kaynakların değerlendirilmesi ve ekonomiye kazandırılması önem taşımaktadır.Merkezi hükümet yardımları da yerel kalkınmanın sağlanmasında başvuru kaynağıdır.Ancak temel olan yerelin ayakta kalabilmesi için mevcut kaynaklarla ne yapılabileceğinin tespit edilmesi ve eksik kaynakların yerini dolduracak üretim yoluna geçilmesidir.Sonuç olarak yerel ekonomik kalkınma yerel dayanışmanın bir sonucu olarak planlama, projelendirme ve uygulama gibi aşamalara tabi tutulması gerekli olan sürdürülebilir stratejiler bütünüdür denebilir.

\subsection{Ticaret Odalarının Yerel Kalkınmadaki Rolüne İlişsin Görüşler}

Yerel ekonomik kalkınmanın gerçekleştirilmesinde sanayi ve ticaret odaları önemli bir aktör olarak hizmet etmektedir. Ülke içinde sanayi ve ticaret odaları yerel halkın kalkınma politikalarına katılımını sağlayan önemli araçlardır. 
Yerel kalkınma yaklaşımı özel sektör, hükümet ve sivil toplum kuruluşlarını kapsayacak şekilde incelendiğinde sanayi ve ticaret odaları özel sektörü temsil eden ve özel sektörün koordinasyonunu üstlenen kuruluşlardır. Yerel ekonomik kalkınma insanların yaşam kalitesini; küçük, orta ve büyük ölçekli firmaların gelişimini, yoksulluğun azaltılmasını, siyaset, kültür ve ekonomi temelinde yapısal ve kurumsal dönüşümünü ifade etmektedir. Küçük firmaların büyümesi ekonomik kalkınma için hayati önem taşımaktadır. Zyl, sanayi ve ticaret odalarının refah, ekonomik kalkınma, girişimciliğin gelişmesi ve yeni mesleklerin yaratılması noktasında katkıda bulunduğunu savunmaktadır (Zyl, 1994'ten ak.: Landsberg, 2016:67). Sanayi ve ticaret odaları, üyelerini bir araya toplayan ve bölgelerini genişletme çabaları verirken kolektif çıkarlarını elde etmek isteyen kuruluşlardır. Yerel ekonomik kalkınmanın gerçekleştirilmesinde odalar yıllar boyu rol değiştirmiş̧tir (Kongolo, 2010:2288-2295).

Yerel ekonomik kalkınma belirli bir alandaki tüm sektörlerden yerel ekonomik faaliyetleri etkinleştirmek ve teşvik etmek için birlikte çalışan yerel katılım süreci olarak tanımlamaktadır. Yerel ekonomik kalkınmanın başarısı birkaç anahtar kavrama bağlıdır. Bunlar hükümet tarafından koordine edilen yerel liderlik ve özel sektör, etkin ekonomik ortamın oluşturulması, gençlerin kalkınma programlarına katılımı, iş yaratma projeleri ve girişimler, yerel ekonominin her seviyesinde yerel iş geliştirme ve kapasite yeteneklerinin kullanılabilirliği ile yaşam kalitesindeki gelişmedir. Yerel iş geliştirme ve rekabet gücünü arttırmak için gerekli olan odalar yerel ekonominin güçlenmesi için gereklidir. Odaların temel amacı, özel sektör kuruluşlarının çıkarlarını korumak, iş dünyası ve yerel ekonomiyi temsil etmek ve teşvik etmek, yatırımları organize etmek, yerel vergi tabanını geliştirmek ve istihdam yaratmaktır. Sanayi ve ticaret odaları özel sektör kuruluşları ve yerel ekonomi arasında tampon görevi görür, yerel yatırımları teşvik ederek istihdamı etkilemektedir (Trousdale, 2005'ten akt.: Landsberg, 2016:68). Yerel ekonomik kalkınma; kamu, özel sektör kuruluşları ve sivil toplum kuruluşlarının yerel halka daha iyi kalitede hizmet vermek için ortak hareket eden bir yaklaşımdır. Yerel ekonomik kalkınma yerel kuruluşların ve yerel işbirliklerinin diyalog ve eylem yoluyla gelişimini sağlamaktadır (Helmsing, 2005'ten akt.: Landsberg, 2016:68).

Yerel ekonomik kalkınma yerel yönetimlerin ve yereldeki firmaların kaynaklarını yönetmek ve yeni işler yaratarak yerel ekonomiyi teşvik etmek için yeni ortaklık düzenlemeleri yapmaktadır. Leigh ve Blakely (2013), ekonomik kalkınmada sanayi ve ticaret odalarının rollerini şöyle sıralamaktadır (Leigh ve Blakely, 2013'ten akt.: Landsberg, 2016:67-69);

1. Sağlayıcılık Özelliği: Yatırımcıların arazi kullanımının planlanması, altyapı, güvenlik, yatırım çekme, kuralların ve etkili yönetimin sağlanması konusunda formüle edilerek kısaltılması.

2. Koordinatörlük Özelliği: Yerel ekonomik kalkınma sürecinin yerel yönetimlerle koordinasyon için anahtar bir program yaratmas1.

3. Mümkün Kılma, İmkân Sağlama Özelliği: Firmalara uzman tavsiyesi, yatırım, yardım, destek, eğitim ve iş planlama desteklerinin verilmesi.

4. Uyarıcı Olma Özelliği: Yerelde özel girişimciyi uyaran ve yeni iş alanlarını çekerek genişleten hibeler, düşük kiralama ve iş kümelerinde hibe desteği ve teşvikler vermesi.

5. Geliştirici Olma Özelliği: Özel sektörün gelişimini uyarmak için elektrik, su, yol ve kanalizasyon gibi temel alt yapı hizmetlerinin sağlanmasıdır.

Odalar, yerel kalkınma stratejilerinin uygulanmasında önemli kurumsal araçlardır. Odalar, yerel ekonomik kalkınma stratejilerinin temel prensipleri olan yerel halk, yerel yönetici, yerel yatırımcı ve girişimci paydaşlarını harekete geçirme, paydaşların eş güdümlü çalışmaları için koordinasyon görevini yürütme, yatırımcı için arazi teminini sağlama, özel firma sahiplerinin önündeki finansal ve yasal nitelikteki engelleri ortadan kaldırma, yereldeki yatırımcıların girdi ihtiyaçlarına cevap verme ve girdi maliyetlerini düşürme, istikrarlı büyüme için yereldeki yatırımcıların ihtiyaçlarının tespiti, yereldeki yatırımcılarla merkezi hükümetin yapılan yatırımlarda süreklilik konusunda yapılan yasal düzenlemelerin ve verilen teşvikleri değerlendirmesi gibi hususları gündemine alan yerel ekonomik kalkınma aktörleridir (Gürler Hazman, 2011:42).

Sanayi ve ticaret odaları yerelde işbirliği sağlamada önemli bir role sahiptir. Yerel yönetimlere bilgi ve deneyim sağlayan odalar, yerel ekonomik gelişimin ve projelerin gerçekleştirilmesi, paydaşlar arası konsensüsün sağlanması ve yoksullaşmış sivil toplum kuruluşlarının yerel kalkınmasını içeren çalışmalar yapmaktadır. Sanayi ve ticaret odalarının faaliyetleri yerel ekonomik kalkınmada yarışı sağlayan, üretim, perakende ve hizmet sektörü gibi sektörlerin ihracatını teşvik eden, sektörel kritik analizlerini yapan kurumlardır. Odaların yerel ekonomiye dair bilgi sağlaması, yerelde toplam ekonomik kalkınmanın gerçekleştirilmesinde yerelde endüstriyel faaliyette bulunanfirmalar arası bağlantı kurulmasını kolaylaştırmaktadır. Sanayi ve ticaret odaları 
günümüzde ticari olmayan eğitim, insan kaynakları, çevresel girişimler, kültürel faaliyetler gibi aktiviteler de geliştirmeye başlamışladır. Odalar bu tür aktiviteleri gerçekleştirerek ekonomik faaliyetleri etkileyen sosyal faaliyetlerin geliştirilmesi için liderlik eden örgütlerdir. Ancak bir oda için öncelik ekonomik gelişmenin sürdürülmesine liderlik etmek olmalıdır. Bu aşamada sosyal faktörler ekonomik faktörlerin önüne geçmemeli yerelde ekonomik şartların iyileştirilmesi öncelikli olmalıdır.

Odalar, yerel ekonomik faaliyet gösteren firma topluluklarının ihtiyaçlarının giderilmesi ve yereldeki girişimcilere iş firsatları yaratılması konusunda bağlantılar kurmaktadır. Yerel yönetimlerin kentlerin ağırlıklı olarak sosyal ve fiziki kalkınmasına ilişkin faaliyetler yürüttüğü göz önüne alındığında, yerelde ekonomik faaliyetlerin organizatörü sanayi ve ticaret odaları olmaktadır. Yereldeki işsizliğin giderilmesi ve iş geliştirme konusunda yerel yönetimlere yardımcı olan odalar, yerel ekonomik kalkınma konusunda yerel yönetimlerle işbirliği halinde hareket edebilirler ve sanayi ve ticaret odalarının diğer yerel yöneticilerle işbirliğinin geliştirilmesi yerel ekonomik kalkınmanın sağlanması için kullanılacak bir araç olarak görülebilir.

Sanayi ve ticaret odaları üretim ve hizmet sektörlerinde üretimin arttırılması için farklı yöntemler belirleyebilir.Bunlara örnek vermek gerekirse odalar yeni teknolojilerin oluşturulması amaciyla üniversitedevlet-sanayi işbirliğinde teknoparklar kurabilir.Üniversitede üretilen bilimin sanayi üretimine aktarıldı̆̆ 1 teknoparklar yerel kalkınmayı doğrudan etkilemektedir.Innovasyonda sürdürülebilirlik yerel ekonomik kalkınmayı doğrudan etkileyen unsurlardandır.Yerel ekonomisi güçlü ülkeler teknolojilerini kendi üretip dünyaya pazarlamakta iken, dünya piyasalarına hâkim olmaktadırlar.Gelişmemiş veya gelişmekte olan ülkeler ise bu teknolojiyi satın alarak üretim faaliyetini sürdürmektedirler.Bu nedenle teknoloji üretimi yerel kalkınmanın gerçekleşmesinde dışa bağımlılığı azaltan bir faktördür. Sanayi ve ticaret odalarından yerel kalkınma konusunda beklenen öncelikler üyelerinin mesleki olanaklarını geliştirmesi, ilgili girişimcilik konularında üyelere eğitim vermesi, yerel ve ulusal düzeyde kolektif bir ses oluşturması ile yerel ve ulusal kalkınma stratejilerinin belirlenmesinde yönlendirici olmasıdır.

\subsection{Türkiye'de Sanayi ve Ticaret Odalarının Gelişimi ve Fonksiyonu}

Türkiye'de sanayi ve ticaret odalarına ilişkin ilk kez 1950 tarihli 5590 sayılı kanunla düzenleme yapılmıştır. Kanun 5174 sayılı olarak 2004'te revize edilmiş ve yürürlüğe girmiştir. Sanayi ve ticaret odalarının görevleri kanunda belirtildiği üzere 12. maddede düzenlenmiş olup odaların yerel ekonomik kalkınmaya ilişkin faaliyetleri şu şekilde özetlenmiştir (www.mevzuat.gov.tr, 2019): Ticaret ve sanayiye dair incelemeler yaparak bölge içindeki iktisadi, sınai ve ticari faaliyetlere ait istatistik tutmak; başlıca ürünlerin piyasa fiyatını takip etmek; yurt içi ve yurt dışı fuar hizmeti vererek üyelere pazar imkânları yaratmak; yurt içi fuar düzenlemelerinde yapılacak müracaatları değerlendirerek birliğe teklifte bulunmak ve ilgili bakanlıkça uygun görülen alanlarda;endüstri bölgeleri,sanayi siteleri, organize sanayi bölgeleri, teknoloji geliştirme merkezleri kurmak ve yönetmektir.

Sanayi ve ticaret odaları üye sanayicilerin kayıtlarını tutarak onları tek çatı altında toplayan kuruluşlardır.Odalar, üye firmaların kuruluşlarında ve ekonomik faaliyetlerinin yürütülmesinde gerekli belgeleri düzenleme, meslek faaliyetlerine ait konularda resmi makamlara başvurma ve üyelerin sorunlarına yönelik arabuluculuk faaliyetiyürütme, vize sağlama gibi hizmetler sunarak bürokrasiyi azaltan uygulamalar yürütmekle görevlidir.Odalar bunun gibi temel görevlerinin yanı sıra yerel ve ulusal ekonomik göstergeleri değiştiren yatırımcıların faaliyetlerini düzenleyen, yatırımcıları devlet yardımları hakkında bilgilendiren ve bu konuda yönlendirme görevi yapan kurumlar olarak da çalışmaktadırlar.Sanayi ve ticaret odaları özel sektör yatırımlarının yerel ve ulusal ekonomiye katkı sağlaması için bazı özel çalışmalar yapmaktadır. Örneğin odalar piyasada haksız rekabet, kartel oluşumunun önüne geçmekte, üyelerinin rekabet edebilirlik gücünü arttıracak ulusal ve uluslararası pazarlarda tanıtımını yapmakta, üye firmaların üretim faaliyetleri ve satışlarını kolaylaştıran ticari bağlantılar kurmaktadır. Girişimciliğin ekonominin gelişmesinde lokomotif güç olduğu bilinciyle odalar yeni girişimcilere ve KOBİ'lere üretim, eğitim ve uzman desteği vererek bir organizatör olarak çalışmaktadır. Odalar ayrıca modern pazarlama tekniği olan fuarcılık hizmetlerini yürütmektedir. Üyelerinin üretim yaptığı sektörleri tespit ederek sektöre uygun doğru fuar seçimini yapan odalar var olan üretimin ulusal ve uluslararası ölçekte tanıtımının, pazarlamanın sağlandığı, yeni iş bağlantılarının kurulduğu, aynı zamanda sektörel bazda üretilen yeni teknolojilerin tanıtılarak katılımcı firmalara transferini sağlandığı fuar aracını kullanmaktadır. Fuarcılık temelde pazarlama ve tanıtım amacı gütse de üretim miktarını arttıracak teknolojik yeniliklerin sektörlerdeki firmalara tanıtımı için ekonomik kalkınmaya doğrudan etki eden araçlardır. Ayrıca fuarcılık yeni iş sahalarının oluşturulması, sektörler arası işbirliklerinin kurulması, kentin markalaşma sürecine de etki etmesi yönüyle önemlidir. 
Odaların yatırım konusunda yeni girişimcilerin desteklenmesi, aktif üretim yapan sanayicilerin ise kar marjını arttırmas1 ve yerel ekonomiye katkı sağlaması bakımından parlamento düzeyinde yasaların biçimlendirilmesindeki rolü büyüktür. Ekonomi konusunda çıkarılan yasalarda hükümete kanaat bildiriminde bulunan sanayi ve ticaret odaları aynı zamanda yerel ekonomideki üretim çıktılarını hükümete raporlar halinde sunarak ekonominin yerel düzlemdeki ilerleyişinin tespiti ve gelecek ekonomi planlarının yapılışında bir referans kaynăg 1 oluşturmaktadırlar.Hazırlanan raporlar ekonomik kalkınmanın aracı olan yatırımlarda üretim açığı veya fazlası olan sektörlerin tespiti ve hükümete bildirilmesinin yanı sıra yeni girişimcilerin eksik olunan sektörlerde üretim yapmasını sağlayarak üretimde etkinliği arttırmaktadır. Ekonomik gelişmeyi engelleyecek unsurları ortadan kaldırmaya çalışan odalar aynı zamanda yerel ekonomik kaynakların tespiti, yerel kaynakların kullanımı ve alınan ekonomik çıktıların derlenmesi noktasında oda, birlik ve ulusal düzlemde bilgi bankası olarak çalışmaktadır. Yani sanayi ve ticaret odaları için ulusal ekonominin yereldeki temsilcileri tanımlamasını yapmak yerinde olacaktır. Yerel, bölgesel ve ulusal kalkınmada yatırımların rolü göz önüne alındığında yerelin yatırım için tanıtımını üstlenen, mevcut yatırımcının ürünlerini satacağı pazarlara erişimini sağlayan ve yeni yatırımcı çekmek için yöre tanıtım faaliyetlerini yürüten odalar yerel kalkınmanın anahtarı olan yatırıma teşvik için çalışmalar yapmakta, bölgeye gelen yatırımcılara güven vererek yatırım konusundaki soru işaretlerini yanıtlamaktadırlar. Ancak yatırım denen üretim faaliyeti süreç ve sonuçları bakımından risklerle dolu bir kavramdır. Yatırımdaki risklerin bertaraf edilmesi ve ekonomik kalkınmaya hizmet edecek hale getirilmesi için devlet, sanayicilere bazı teşvik ve destekler vermektedir. Genel olarak devlet yardımları olarak ifade edilen teşvikler, bölgesel gelişmişlik farklarının minimum düzeye çekilmesi ve ekonomik dengesizliklerin giderilmesi noktasında etkin bir araç olarak kabul edilmektedir. Makro düzeyde bölgeler arası eşitsizliklerin giderilmesini hedef alan teşvikler mikro düzeyde çeşitli riskler ve muhtemel imkânsızlıklar dâhilinde üretim yapan sanayici için bir kurtarıcıdır.

Teşvikler bölgelerin gelişmişlik düzeylerine göre çeşitlilik ve seviye farkı göstermektedir. Türkiye'de ise sanayiciye verilen teşvikler genel olarak şu şekilde sıralanabilir: Devletin özel sektöre bedelsiz arazi ve bina tahsis ettiği ayni teşvikler; düşük faizli, uzun vadeli kredileri temin ettiği nakdi teşvikler; yatırım indirimi, vergi ertelemesi, vergi resim ve harçlarından muafiyet ve vergi iadesi gibi vergi kanunlarında müdahaleler sonucunda oluşan vergi teşvikleri, riskli yatırımlarda devletin garantör olduğu ve proje maliyetlerinin bir kısmını karşıladığı ve yatırım sigortalarının yapıldığ garanti ve kefaletler; iletişim, ulaşım, enerji ve arıtma tesisleri yoluyla enerji destekleri ile üretici firmaların KOBI'lere yönelik ham madde fiyatının sabitlenme garantisinin verilmesi, pazar araştırmasının yapılması, üretimde projelendirmenin yapılması ve çalışanların eğitimlerine yönelik verilen desteklerdir. Teşvikler yatırımın kapsamına göre yerel, bölgesel veya sektörel olabilmektedir. Vergi muafiyeti, vergi indirimi, KDV istisnası gibi bazı teşvikler ulusal düzlemde hiçbir sektör ve bölgesel ayrım yapılmaksızın verilmektedir. Bazı teşvikler ise yenilenebilir enerji, havacılık ve uzay sanayi gibi belli sektörlere sağlanmakta ve bu sektörlerin yelpazesinin genişletilerek katma değerinin arttırılmasına yönelik çalışmalar yapılmaktadır (Bozdoğan, 2014:294-295).

Yerel ekonomik kalkınmadan beklenenlerin vergi tabanının genişlemesi, istihdam yaratılması, yeni iş sahalarının oluşturulması, mevcut firmaların büyütülmesi, ekonomik yapıda çeşitliliğin arttırılması, daha yüksek ücretli iş olanaklarının oluşturulması, girişimciliğin gelişmesi, istikrarlı ve sürdürülebilir büyümenin sağlanarak sosyal ve ekonomik eşitliğin sağlanması ve sosyal refahın arttırılması olduğu söylenebilir. Bunların gerçekleştirilmesinde sanayi ve ticaret odaları katalizör görevi üstlenmektedir (Gürler Hazman, 2011:29). Dolayısıyla yerel kalkınmanın kilit noktası olan yatırımların organize edilmesi, yatırımcıların yararlanabileceği avantajlardan haberdar edilmesi ve yatırımcının ihtiyaçları doğrultusunda kanun düzenlemelerinin yapılması konusunda manevi yaptırım gücü olan sanayi ve ticaret odalarının katkıları önem taşımaktadır.

\section{TORBALI TICARET ODASI'NIN TORBALI'NIN YEREL KALKINMASINA YÖNELIK FAALIYYTLERI}

Bu bölümde Torbalı Ticaret Odası başkanı, dış ticaret uzmanı, KOSGEB temsilcisi ve Ege İhracatçı Birlikleri basın müşaviri ile 13.06.2019 -14.06.2019 tarihleri arasında yapılan yüz yüze görüşmeler sonrası elde edinilen bilgiler yorumlanarak Torbalı kentinin yerel kalkınmasına yönelik faaliyetleri başlıklar halinde aşağıda sunulmuştur. 


\subsection{Torbalı Ticaret Odası'nın Oda Üyelerine Yönelik Faaliyetleri}

1978 yılında kurulan Torbalı Ticaret Odası, 2012'den beri A sınıfı oda kategorisine girmiş ve akredite olarak hizmet vermektedir. Oda yönetimi, bünyesinde kayıtlı 389'u ihracatçı olmak üzere 2513 aktif üyenin sorunları için üyelerini periyodik olarak haftada bir gün ziyaret etmektedir. Ayrıca haftada bir gün oda bünyesinde çapraz kaynaştırma toplantıları düzenlenmektedir. Toplantılarda amaç üye sanayicileri birbirleriyle tanıştırarak iş ortaklıkları kurmasının yolunu açmaktır. Toplantılarda sektörel, yerel ve bölgesel sorunların tespiti yapılmaktadır. Yapılan tespitler Türkiye Odalar ve Borsalar Birliği'nin sanayi ve ticaret şuralarında ve TOBB'a bağlı ticaret odaları toplantılarında Torbalı adına söz alınarak iletilmektedir. TBMM'de milletvekillerine ve ilgili komisyonlara bildirimlerde bulunulmaktadır.Sorunların çözümü için önce tespit, daha sonra sorunların yer aldığı dosyaların meclise sunumu şeklinde bir yol izlenmektedir.Oda faaliyetlerinde TOBB'un Türkiye'deki ilçe odalarına yönelik direktifleri etkili olmaktadır.Torbalı Ticaret Odası TOBB'un "Oda Ne İşe Yarar?" sorusunu cevaplayabileceği ölçüde çalışmalar yapmakta ve yürüttüğü faaliyetler ile sadece üye aidatlarının ödendiği, prosedürel hizmetlerin yerine getirildiği bir oda olmaktan uzak bir oda olarak sanayicilerine hizmet etmektedir.

Odaya, faaliyetlerini sağlıklı yürütmesi ve akademik destek sağlaması için TOBB'un önerisiyle Ege Üniversitesi’nden bir akademik danışman atanmıştır. Ege Üniversitesi Sürekli Eğitim Merkezi (EGESEM) ile Torbalı Ticaret Odası'nın Stratejik Planlarına Yönelik Eğitim Programları Yürütme Projesi üzerine protokol yapılmıştır. Projede amaç 2023 ulusal ekonomi hedeflerine ulaşabilme noktasında bir paydaş olarak Torbalı'nın neler yapabileceği sorusunu cevaplamaktır. Proje kapsamında tarıma dayalı sanayinin geliştirilmesine yönelik çalışmalar yapılması planlanmaktadır.

Akademik danışman gözetiminde yürütülen oda faaliyetlerinde Torbalı'da tarıma dayalı sanayide Torbalı'nın büyümesi için yapılması gereken çalışmaların neler olabileceği ekseninde hareket edilmiştir. Ege Üniversitesi ile sanayi, oda ve üniversite işbirliğinde protokoller yapan oda, bu kapsamda çeşitli çalıştaylar ve eğitimler düzenleyerek alınan danışmanlık hizmetlerini sahada uygulamıştır. Üyelerinin ticari iş ve işlemlerinin yürütülmesi ve bu konuda bürokrasiyi azaltmak için oda; dış ticaret ve teşvik birimi, mali muhasebe birimi, hukuk servisi gibi bölümler açmıştır. Yeni kurulan birimler üyeye endeksli olup sanayicilerin pazar bulmaları için araştırma geliştirme projeleri yürütmektedir. Oda, yurt dışında ticaret odaları ile işbirlikleri kurarak ticari ilişkiler geliştirmekte, üyeler adına pazar araştırması yapmaktadır. Yurt içi ve yurt dışı fuar çalışmaları yürüterek ticaret hacminin geliştirilmesini hedeflemektedir.Ayrıca yurt dışındaki gümrük ataşelikleri ile bağlantı kurarak odaya kayıtlı ihracatçı üyelerin iletişim bilgilerinipaylaşmakta, aynı şekilde o ülkede bulunan sanayicilerin iletişim bilgilerine erişerek ülkeler arası dış ticarete katkı sunmaktadır.Buna bağlı olarak Torbalı'daki sanayici üyelerin dış ticaret hacmi geliştirilmektedir.Oda, sektörel bazda fuar çalışmaları yapmaktadır.Ayrıca ihracatçı üyelerin hangi ülkeye nasıl ihracat yapacağı konusunda üyelere yönelik danışmanlık hizmeti vermektedir. Oda, İzmir Ticaret Odası (IZTO), Ege Bölgesi Sanayi Odası (EBSO) ve Ege İhracatçı Birlikleri (EIBB) ile ortak yürüttüğü ilçede Mobilya Organize Sanayi Bölgesi’nin kurulmasına yönelik yaptığı çalışma ile ilçenin bir mobilya üssü olması yönünde proje geliştirmekte ve hedefler belirlemektedir. Bu kapsamda oda, ilçeyi Türkiye'de ve dünyada tanınan bir mobilya üssü olmasına çalışmaktadır.

Oda, uluslararası firmalarla bağlantılar kurduğu için oda binasını yabancı sanayicilerin de ihtiyaçlarını karşılayacak donanıma kavuşturmuş olup, üye sanayicilerin yabancı dil desteği alabilmeleri için ilçede bulunan yabancı dil kurs merkezleri ile protokoller yapmıştır. Bunun yanı sıra ihracatçı üyelerin yabancı dil hizmeti alabilmeleri için tercüme ofisleri ile anlaşmalar yapmış ve diş ticaret konusunda dil desteği sağlayabilmeleri konusunda yönlendirme yapmaktadır. Oda, Torbalı'da yatırım yapmak isteyen sanayicileri ilçede üretimi olmayan veya üretimde eksikliği bulunan sektörlere yönlendirme görevini de üstlenmiştir. Aynı alanda üretim fazlalığı oluşabilecek sektörlerin ilçede yığılma oluşturmasını engellemekte, bu vesile ile sanayicinin de yatırımını daha iyi planlayarak daha etkin hale getirmesini ve pazar konusunda sıkıntı yaşamamasına yardımcı olmaktadır. TOBB'un da açık iş alanlarını belirtmesiyle ticaret odası olarak ilçede iş alanlarını belirlemede koordinatörlük yapmaktadır. Oda, ilçe ekonomisinin gelişmesini sağlayan üyelerinin yaşadığı sektörel sorunları gidermek amacıyla çalışmalar yapmaktadır. Bu kapsamda geçen yıllarda beton ve demir fiyatlarının yükselmesiyle Torbalı'da yapılan inşaatlar olumsuz etkilenmiş, bazı inşaatlar durma noktasına gelmiştir. Bu durum inşaat sektöründe ve konut satışında İzmir ilçeleri arasında son yıllarda ilk 3 ve 4'e giren Torbalı için duraklatıcı bir süreç oluşturmuştur. Oda, üyesi olan müteahhitlere beton ve demir fiyatlarının yükselmesine istinaden müteahhitlerin demir ve beton alımını durdurmaları ve yüksek fiyattan malzeme almamaları konusunda uyarmış, ilçede beton ve demir fiyatlarının düşmesini sağlamıştır.

Oda, ticaret hacminin genişlemesi için elektronik ticaretin üyeleri arasında yaygınlaştırılması amacıyla eğitimler vermektedir. Türkiye'de e-ticaretin yaygınlığının \%2 ve \%3'lerde olduğunu belirten oda yönetimi, Torbalı' da da bu oranın yükseltilmesi için eğitim ve bilgilendirme desteği vermektedir. Devlet tarafından e-ticaret konusunda 
networkler, sanal fuarlar, sanal galerilerin kurulmasına ilişkin verilen teşvikleri sanayiciye aktarma konusunda bilgi desteği sağlayan oda, Torbalı'da e-ticaret uygulamalarının uzun vadede sonuç alınabilecek bir çalışma olduğunu öngörmektedir.

\subsection{Torbalı Ticaret Odası'nın İlçenin Tanıtımına Yönelik Faaliyetleri}

Torbalı'nın gelişmişliği konusuna yerel ve ulusal basında sık sık yer veren Torbalı Ticaret Odası, Hürriyet Ege, Milliyet Ege, Posta Gazetesi Ege Eki, Egeli Sabah, Habertürk Egeli, Yeni Asır, TRT, NTV, CNN Türk, Kanal 7, Kanal 35, Ben TV, FRM Net TV, Anadolu Ajansı, Rus Ans TV gibi yazılı ve görsel basın yayın organlarına demeçler vermekte ve uluslararası medya kuruluşlarına da ilçedeki ekonomik faaliyetler konusunda tanıtım faaliyetleri yürütmektedir. Odanın Torbalı'nın tanıtımına dair en büyük diğer hamlesi ilçenin tarım ve sanayi ekonomisini bir araya getirerek marka değer yaratacak zeytin kolonyası üretimini özel sektör kuruluşlarına yaptırması ile bunu odalar arasitoplantılarda ve parlamento ziyaretlerinde yetkili ve bürokratlara götürerek tanıtmasıdır. İlçede zeytinin önemli bir ihraç ürünü olması ve tarıma dayalı sanayide ihracatta önemli bir yere sahip olması zeytin kolonyasının tanıtım amaçlı üretimine ortam hazırlamıştır. Ege İhracatçı Birlikleri (EIB) 2018 verilerine göre ilçede 48 milyon doların üstünde zeytin ve zeytinyağı ihracatı gerçekleştirilmiştir. Ayrıca EİB 2018 verilerine göre Torbalı'dan 1 ihracatçı üye, birlik tarafından sektör öncülerinin belirlendiği “İhracatın Ylldızları" isimli ödül töreninde ihracatta sektör 1.'si olmuştur.

2018 yılı Torbalı Ziraat Odası verilerine göre ilçe zeytin varlığının \%90’1 yağlık, \%10’u sofralık üretime uygundur ve ilçede 17 adet zeytinyağı sıkım tesisi bulunmaktadır. İlçede zeytinyağı, mısır ve pamukla birlikte desteklenen 3 üründen biridir. Destekleme miktarı ise kg başına 75 kuruştur. Torbalı İlçe Tarım ve Orman Müdürlüğü 2018 verilerine göre hükümet tarafindan zeytinyağı üretimine ilçede toplam 1.192.731.890 TL destekleme verilmiştir. Yine İlçe Tarım ve Orman Müdürlüğü 2018 verilerine göre ilçede 58.350 dekar alanda yağlı zeytin üretimi yapılırken, 1.312 .435 yağlık zeytin ağacı bulunmakta ve 45.935 ton ürün elde edilmektedir. Torbalı'da sofralık zeytin üretim alanı 14.058 dekar iken, yağlık zeytin üretim alanı 61.202 dekardır. İzmir genelinde ise sofralık zeytin üretim alanı 105.174 dekar iken, yağlık zeytin üretim alanı 865.582 dekar olduğu göz önüne alındığında ilçenin İzmir'deki toplam zeytin üretimine etkisi anlaşılacaktır. Zeytin ve zeytinyağı üretiminde Ege Bölgesi Sanayi Odası ise İzmir Zeytin, Zeytinyağı ve Teknolojileri Organik Ürünler Fuarı düzenlemekte olup fuar bugüne kadar $7 \mathrm{kez}$ organize edilmiş, 322 stantla, 10.800 katılımcı ile yürütülmüştür. İlçede zeytinyağı sıkım fabrikalarına İzmir Kalkınma Ajansı (İZKA) tarafından da destekler verilmiştir. 2008'de İZKA'nın Torbalı'daki KOBİ'lere verdiği destekler kapsamında 1 firma organik zeytinyağı üretimi için depolama ve şişeleme amaçlı teknoloji yineleme projesinde desteklenmeye layık görülmüştür.

\subsection{Torbalı Ticaret Odası'nın İşsizlikle Mücadeleye Yönelik Faaliyetleri}

İstihdama katkı sağlamak amacıyla İŞKUR Hizmet Birimi'ni kurmuş olan oda, iş arayanlarla işçi arayanları bir araya getirmeye çalışmakta ve odaya yapılan başvurularda işçi-işveren eşleştirmesi yaparak ilçede istihdam düzeyini arttırmaya çalışmaktadır. Oda, bu eşleştirme yapılmadığında ise iş arayanların Torbalı İşKUR Hizmet Noktası'na yönlendirilmesini sağlamaktadır. Oda, 2015 yılından itibaren her yıl İŞKUR-Torbalı İlçe Milli Eğitim Müdürlüğü ile işbirliği yaparak "Kariyer ve İstihdam Fuarı" düzenlemekte, burada sanayici ile mezun öğrencileri bir araya getirmekte ve istihdam konusuna hizmet etmektedir. 2018 Kariyer ve İstihdam Fuarı'nda 60 firma ve 43 meslek lisesi stant açmış olup 60 insan kaynakları yöneticisi ve 450 işsiz yüz yüze görüştürülmüştür.

Oda, 2011'de KOSGEB Temsilciliği açarak ilçede girişimcilik faaliyetine başlayacak olanlara ve hali hazırda girişimci olup ekonomik faaliyetini sürdüren Küçük ve Orta Büyüklükteki İşletmelere (KOBİ)lere yönelik desteklerin verilmesi konusunda yönlendirmeler ve tanıtımlar yaparak eğitimler vermektedir. Torbalı KOSGEB Temsilciliği'ne bağlı 2700 firmadan girişimci olan 850 firmaya ihtiyaç duyacağ girişimcilik eğitimlerini veren oda, 2011 yılına kadar Güney Ege Havzası'nı kapsayacak şekilde hizmet vermiştir. Bu tarihe kadar başta Torbalı ilçesi olmak üzere İzmir'in Tire, Selçuk, Menderes ve Bayındır ilçelerinde üretim yapan KOBİ'lere dönük hizmet veren temsilcilik, 2011'den sonra Tire, Selçuk ve Bayındır'da temsilcilikler açılmasına rağmen, ilçelere coğrafi yakınlığı ve firmalarla yakın ilişkileri itibariyle Gaziemir ve Buca ilçelerini de kapsayacak şekilde hizmet vermektedir. Temsilcilik 2015'ten beri 20 KOSGEB Uygulamalı Girişimcilik Eğitimi vermiştir. Eğitimlerden 600 girişimci yararlanmıştır. Temsilcilik kurulduğu günden bu yana 2000 üye kaydı gerçekleştirmiş olup, 50'nin üzerinde kadın girişimciyi ilçeye kazandırmıştır. Geçtiğimiz yıllarda genel ekonomik faaliyet konularında hizmet veren temsilcilik, üretimin arttırılması ve toplam üretim hacminin 
genişletilerek katma değeri yüksek üretime geçilmesi için makine ve teçhizat üretiminde desteklemeler vermeye başlamıştır. Girişimcilere yurt içi fuar desteği, yurt dışı iş gezisi desteği, eğitim desteği, tasarım desteği, enerji verimliliği desteği, nitelikli eleman desteği, sınai mülkiyet hakları desteği, belgelendirme desteği, yazılım desteği, proje desteği ve istihdam desteği gibi konularda destek veren KOSGEB, üyelerine desteklemeler konusunda bilgi vermektedir. KOSGEB Torbalı'nın yeni KOBİ'lerin faaliyetlerinin takibi ve yeni iş alanlarına yönlendirilmesi konusunda faaliyetleri de bulunmaktadır.

Temsilcilik, MEYBEM A.Ş. ile inşaat, maden gibi tehlikeli işlerde çalışan işçilere yönelik mesleki eğitimler vermekte ve belgesiz çalışan iş̧̧ilere yönelik sınavlar düzenleyerek belgelendirme yapmaktadır. Torbalı Ticaret Odası, ekonomik kriz dönemlerinde "Torbalı'nın Parası Torbalı'da Kalsın" kampanyasını yürüterek yerel halkın Torbalı'dan alışveriş yapmasını sağlayarak ilçe esnafının ayakta kalmasını destekleyen çalışmalar yürütmektedir. Ayrıca oda, ulusal düzeyde meydana gelen terör olayları ve ekonomik krizlere karşı ihtiyatlı davranma eğilimine giren yatırımcıları teşvik etme ve ilçede yatırım faaliyetlerini yürütmeleri konusunda "Ayrıştırmaya Karşı Birleştirici Ol" kampanyası yürütmüş olup, 15 Temmuz darbe girişiminde ilçede üretim faaliyetini sürdüren 60 yabancı yatırımcıya İngilizce mektuplar göndererek siyasi karışıklıkların ekonomik faaliyetleri doğrudan etkilemeyeceğine dair güvence vermiş, üreticinin üretim sürecine destek olmuş ve güvenli bir atmosfer oluşturmuştur.

\subsection{Torbalı Ticaret Odası'nın Yurt Dışındaki Ticaret Odaları ve Fuarcılık Hizmetlerine Yönelik Faaliyetleri}

Torbalı Ticaret Odası, Türkiye Odalar ve Borsalar Birliği (TOBB)'un açıkladığı KOBİ'lere yönelik KOSGEB destekli yurt dışı fuar gezisi düzenlemeye ilişkin yönergeye istinaden odaya kayıtlı üyelerin pazar imkânlarını araştırması ve yeni iş ortaklıkları kurması noktasında çalışmalar yürütmektedir. Bu kapsamda yurt dışı fuar desteklemelerinin ilk adımı, yurt dışı fuarın “Milli Katılım Organizasyonu Düzenlenecek Fuarlar Listesi"'nden seçilmesidir. İkinci adımı ise ulaşım, konaklama, tercüme ve rehberlik hizmetleri için A sınıfı belgeli bir seyahat acentesi ile anlaşma oluşturmaktadır. Üçüncü adımda KOBI'lerin gezi kapsamında karşı ülkede meslek kuruluşu, sanayi bölgesi, fabrika, teknopark veya finans grupları ile en az bir toplantı organize etmesi, dördüncü adımda gidilecek fuarın KOBİ tarafından NACE kodları uyumlu en az 10 katılımcı işletmenin belirlenmesi, beşinci ve son adımı ise yurt dışı iş gezisi desteği almak isteyen KOBI'lere yönelik açılan web sitesinden başvuru yapılması oluşturmaktadır. Yurt dışı fuar desteğinin kapsamı konaklama giderleri, havayolu, karayolu, demiryolu ve denizyolu ulaşım giderleri, tercüme ve rehberlik giderleri ile fuar giriş ücretleri ve toplantıorganizasyon giderleridir. Destekler kapsamında her bir KOBİ için 4000, 5000 ve 6000 TL tutarındaki işletme giderleri için giderlerin \%60’1 KOSGEB tarafindan desteklenmekte olup firmaların destekleri alabilmesi için programa uygun hareket etmesi, katılımcıların sektör uyumunu sağlaması ve NACE kodlarına uygun sektör eşleştirmesi yaparak geziye katılacak kişilerin işletme sahibi, ortağ 1 veya çalışanı olması gibi şartlar aranmaktadır.

Uluslararası anlamda Almanya Bremen Ticaret Odası ile anlaşması olan oda, Bremen ve Almanya'nın diğer şehirlerinde ne tür ticari ortaklıklar kurularak ticaret hacminin geliştirilebileceğine dair çalışmalar yürütmektedir. İhracat yapmayan firmaların ihracat yapmasını teşvik etme, ihracat yapılan sektörlerin ise gelişmesini sağlayarak sektörel çeşitliliği arttırma, bölge çeşitliliği yaratma konusunda çalışan odanın Rusya'da St. Petersburg Ticaret Odası ile protokolleri bulunmaktadır. Moskova Sanayi ve Ticaret Odas1, St. Petersburg Ticaret Odası, Bremen Ticaret Odası, İtalya Ticaret Odası ve Batum Ajara Ticaret Odası ile ikili işbirlikleri yapan oda, yakın tarihte Tiflis'teki İş Forumu'na katılım göstermiş, Polonya İş ve Yardımlaşma Forumu'nu ziyarette bulunmuştur. Oda ayrıca Moskova'da Rus-Türk iş adamları Birliği'niziyaretlerde bulunmaktadır.

Yurt içi ve yurt dışı iş gezileri ve fuarcılık hizmetleri yürüten oda, 2019'da yurt içinde Diyarbakır, Mardin, Şanlıurfa, Bursa, Aydın, Kayseri'ye iş gezileri düzenlemiş, yurt içi fuarlara katılım göstermiştir. Yurt dışında Rusya, İtalya, Makedonya, Hırvatistan ve Balkan ülkeleri ile fuarcılık çalışmaları yürütmektedir.Oda yönetimi yurt içindeise mobilya sektörü üzerine etkinlikler düzenlenmeyi planlamaktadır.Yurt dişındaki gümrük ticaret ataşelikleri ile irtibat halinde olan oda, gümrük ticaret tarife numaralarına göre yurt dışındaki firma listelerine erişmektedir.Gümrük vergileri ve ihracat konusundaki masraflar ile ilgili üyeleri bilgilendirmekte ve üyeleri tercüme hizmetleri için anlaşmalı olduğu tercüme ofislerine göndermektedir.

Oda, üyeleri için pazar oluşturabilecek olan başta ABD ve Almanya olmak üzere, Avrupa Birliği ülkeleri, Orta Doğu ve Kuzey Afrika ülkelerini de kapsayan tüm ülkelerin ateşelikleri ile resmi yazışmalar yapmakta ve yurt dışındaki firma sahiplerinin iletişim bilgilerine erişerek üyelerine bildirmektedir. Oda, firma sahiplerini bir araya getirerek ticari ortaklıklar kurulmasını ve ticaret hacmini arttırmayı hedeflemektedir. İlçedeki sanayi üretiminde 
genel olarak tüm sektörlere yer verilirken, mobilya konusunda ihtisaslaşma odanın gündemindedir. Özellikle Torbalı Organize Sanayi Bölgesi arazisine eklenerek 3 parsel üzerinde 770 dönümlük alanda inşa edilecek olan Mobilya Organize Sanayi Bölgesi, bu ihtisaslaşma çabasının en önemli örneğidir. Minimum sanayi parseli büyüklüğünün $3.000 \mathrm{~m}^{2}$ olacağı OSB'nin 3 yıl içerisinde alt yapısının hazır hale getirilmesi hedeflenmektedir. Altyap1 yatırım bedelinin $\mathrm{m}^{2}$ de 150-200 TL olacağı öngörülmektedir. Mobilya OSB, İzmir'de kurulacak olan 14. OSB olması, içerisinde yatırım yapacak yatırımcıların Türkiye'de uygulanan mevcut sanayi teşviklerine ek olarak fabrika inşaatı bitim tarihinden itibaren 5 yıl boyunca emlak vergisinden, atık su bedelinden, bina inşaat harcı ve yapı kullanma izni harcından ve belediyenin çevre temizlik vergisinden muaf olması bakımından avantajlidır.

$\mathrm{Bu}$ nedenle mobilya ve inşaat fuarlarına katılım odanın gündemindedir. Fuarlara katılım konusunda İtalya ve Almanya Mobilya Fuarlarına katılım planlanmakta olup, yap1 sektöründe Irak Yap1 Fuarı'na katılım hedeflenmektedir. Oda, Torbalı 2018 ihracatında \%8,9 sektörel payı ve 105 milyon dolar ihracat rakamıla 2. sırada olan mobilya sektörünün ön plana çıkarılması için çalışma yürütmektedir. Bu çalışmalar kapsamında Makedonya Büyükelçisi Torbalı'da ağırlanmış ve Torbalı'daki iş olanakları konusunda bilgilendirilerek Makedonyalı firma sahiplerine davette bulunulmuştur.

Tablo 1. Torbalı Ticaret Odası Dış Ticaret Birimi’nin İhracatçı Üyelere Yönelik Faaliyetleri

\begin{tabular}{|c|c|}
\hline Sira No & Faaliyet Konuları - Faaliyet Düzenleme Sıklığı \\
\hline 1 & Üyelerin dış ticaret konusunda gerekli altyapıyı oluşturmaları adına eğitimler düzenlemek (Ayda 1 kez). \\
\hline 2 & Üyelerin dış ticaret konusundaki isteklerini gerek oda gerekse firma içerisinde birebir görüşüp tartışmak. \\
\hline 3 & Üyelerin ihracat ve ithalat ürünlerini belirlemek. \\
\hline 4 & $\begin{array}{l}\text { Üyeler için ihracat-ithalat ürünlerine uygun hedef pazar araştırması yapmak ve bire bir görüşmeler yaparak } \\
\text { firma sahipleri ile incelemek. }\end{array}$ \\
\hline 5 & Üyelere hedef pazarlar ile ilgili düzenlemeleri, pazara giriş için genel bilgiler ve fuar bilgilerini sağlamak. \\
\hline 6 & $\begin{array}{l}\text { Üyelere seçilen hedef pazarlarla ilgili ataşelik, müşavirlik veya diğer kanallar yolu ile firma iletişim bilgilerini } \\
\text { sağlamak. }\end{array}$ \\
\hline 7 & Üyeler için gerektiğinde bu firmalarla görüşmeler sağlayarak sonuç almalarına yardımcı olmak. \\
\hline 8 & $\begin{array}{l}\text { Üyelere devlet destekleri ile ilgili bilgi vermek ve gerektiğinde profesyonel bir danışman şirkete } \\
\text { yönlendirmek. }\end{array}$ \\
\hline 9 & $\begin{array}{l}\text { Odanın çalışma içeriğinin firmalarla uyumlu yönetilmesi için üyeler için sektörel bazda E-Posta ve SMS } \\
\text { grupları oluşturmak. }\end{array}$ \\
\hline 10 & $\begin{array}{l}\text { Sektörel bazlı hedef pazar araştırmaları yapıp, pazarlar ile ilgili güncel bilgilerin üyelere SMS veya E-Posta } \\
\text { yoluyla iletilmesi ( } 6 \text { ayda } 1 \mathrm{kez}) \text {. }\end{array}$ \\
\hline 11 & $\begin{array}{l}\text { Sektörel bazlı uluslararası fuarları ve katılım teşviklerini üyelere SMS veya E-Posta yoluyla bildirmek (Fuar } \\
\text { tarihinden } 3 \text { ay önce). }\end{array}$ \\
\hline 12 & Uluslararası fuarlar için üyelerin toplu katılımına veya ziyaretine öncülük etmek (Yılda 1 kez). \\
\hline 13 & Yurt dışı ülke veya şehir ticaret odalarıyla görüşüp onlarla ortak etkinlikler düzenlemek (Yılda 2 kez). \\
\hline 14 & Gümrük mevzuatı ile ilgili yeni gelişmeleri takip ederek üyeleri bilgilendirmek. \\
\hline 15 & Üyelere dış ticarette alıcı ve satıcı arasındaki sorumluluk ve riskleri anlatmak. \\
\hline 16 & Üyelere Torbalı Ticaret Odası Dış Ticaret Bölümü ile ilgili anket düzenlemek (Yılda 1 kez). \\
\hline
\end{tabular}

Kaynak: Torbalı Ticaret Odası Dış Ticaret Birimi ile mülakat verilerinden hareketle hazırlanmıştır. 


\subsection{Torbalı Ticaret Odası'nın İlçe Kanaat Önderliğine ve Meclisteki Yasama Sürecine Yönelik Faaliyetleri}

Torbalı Ticaret Odası; Torbalı Organize Sanayi Bölgesi, Pancar Organize Sanayi Bölgesi ve Mobilya Organize Sanayi Bölgesi'nin kuruluş aşamalarında ilçe sınırlarında organize sanayi bölgelerinin kurulması ve organize sanayi bölgelerine ulaşımın kolaylaştırılması için İzmir-Aydın Otoyolu'ndan cep açılması için kanaat önderliği yapmaktadır. Oda, Ege Bölgesi Sanayi Odası ile birlikte organize sanayi bölgelerinin kurulmasına dair ortak çalışma yürütürken, Karayolları Genel Müdürlüğü ile organize sanayi bölgelerine ulaşım konusunda çalışmalarını sürdürmektedir. Oda ayrıca Pancar Organize Sanayi Bölgesi’ne doğal gaz getirilmesi konusunda kanaat önderliği yapmıştır.

İzmir Çevre ve Şehircilik İl Müdürlüğü tarafından ilçede faaliyet gösteren sanayi kuruluşlarına yapılan denetimler sonucunda günde $14.000 \mathrm{~m}^{3}$ kimyasal atığın 13 km'lik kanalizasyon şebekesi ile Fetrek Çayı'na oradan da İzmir'in Selçuk ilçesindeki Pamucak Mevkii'nden denize döküldüğü için deniz kirliliğine neden olduğu tespit edilmiştir. Bu kapsamda Torbalı Ticaret Odası kurumlar arası görüşmeler sonucunda İzmir Su ve Kanalizasyon İdaresi (IZSU) ile ilçe sınırlarında bulunan Yazıbaşı ve Çaybaşı Mahalleleri'ne endüstriyel arıtma tesislerinin ivedilikle yapılması konusunda çalışma yürütmüştür.

Oda, ilçede 1200 işletmeye kalifiye eleman yetiştirmekte zorlanan 500 öğrenci kapasiteli Torbalı Endüstri Meslek Lisesi binasına ek olarak ilçede son yıllarda artış gösteren mobilya fabrikaları sebebiyle sanayicinin yoğun şekilde faaliyet gösterdiği Yazıbaşı veya Ayrancılar Mahalleleri'ne ek bina yapılması ve buradaki atıl binaların değerlendirilmesi ile ilgili görüş bildirmiştir. Odaya kayıtlı sanayicilerin odaya bulunduğu bildirimlerden ilçedeki fabrikalarda istihdam açığı olan bölümler endüstriyel kalıpçılık, gıda teknolojisi, iklimlendirme ve soğutma teknolojisi, kaynak teknolojisi, kontrol ve otomasyon teknolojisi, makine, resim ve konstrüksiyon, mobilya ve dekorasyon, tekstil teknolojisi olarak tespit edilmiştir. Oda, ilçede sanayicinin ihtiyaç duyduğu, ara eleman açığının olduğu bölümlerin açılmasına yönelik Dokuz Eylül Üniversitesi ile YÖK nezdinde çalışmalar yürütmektedir. Torbalı Ticaret Odası, İzmir Ticaret Odası ile Torbalı'dameslek lisesi kampüsü kurulması noktasında TOBB Ekonomi ve Teknoloji Üniversitesi (ETÜ) ile çalışmalar yapmaktadır.

Oda, ilçede Yazıbaşı, Pancar ve Ayrancılar Mahalleleri'nde yoğunlaşan ortalama 400 sanayi kuruluşunun elektrik kesintisi sorununu çözmesi için bahsi geçen bölgelerde eski iletim hatlarının yer altına alınarak belli noktalarda enerji dağıtım merkezlerinin kurulması gerekliliğini tespit etmiştir. İlçede İzmir Banliyö Taşımacılığı Anonim Şirketi (IZBAN) raylarının etrafının kapatılması kente bölünmüşlük hissi vermektedir. Araç geçişleri için kentin iki yakasına yapılan köprülerin darlığı hem kaza sebebi oluşturmakta hem de 11 metre yükseklikte olduğu için yapı çevresindeki evlerin içinden geçiyor hissi vermektedir. İZBAN köprülerinin ilçeye inşa edilmemesi için kamuoyu oluşturan odanın çalışmalarından netice alınamamıştır. İlçede bulunan 5 taş ocağının Metropolis Antik Kenti'nin bulunduğu Ahmetli-Yeniköy arasında bulunması ve günlük 300 kamyon sevkiyatınbu bölgeye yakın bir noktadan sağlanarak şehir içinden yapılması antik kente gelecek ziyaretçilerin bölgeye daha sağlıklı ulaşım sağlayabilmesi konusunda risk taşımaktadır. Bu sorunun çözümü için İzmir-Aydın Otoyolu'nun Torbalı gişelerinin geriye alınması gerekmektedir. Torbalı Ticaret Odası bu sorunun çözümü için kamuoyu oluşturmakta ve ilçedeki sorunların tespitine yönelik araştırmalar yapmaktadır. Oda, yerel sorunları merkezi hükümete taşıma konusunda arabuluculuk görevini üstlenmiş, yerel sorunların çözümünde ilçedeki yerel yönetimlerle işbirliği halinde çalışmaktadır.

Torbalı Ticaret Odası, ilçede olumsuz etki yaratabileceği öngörülen uygulamaların karşısında durmuş ilçede İzmir Büyükşehir Belediyesi tarafından katı atık bertaraf tesisinin yapımının geri çekilmesi için ilçe genelinde dilekçeler toplayarak sivil insiyatif oluşturmuş ve dönemin Orman ve Su İşleri Bakanı ile yaptığı görüşmelerle ilçeye tesisin yapılmasını durdurmuştur. Torbalı Ticaret Odası ayrıca mecliste yapılan kanunlar konusunda görüş bildiren bir kuruluştur. Bu kapsamda oda, yasama sürecine dâhil olmaktadır. TOBB'a sanayicilere yönelik yapılan kanunlarda görüş sorulduğunda TOBB da il ve ilçelerdeki sanayi ve ticaret odalarının görüş ve önerilerini almaktadır. En son Kıdem Tazminatı Fonu'nun Yeniden Düzenlenmesine Dair Yönetmeliğin hazırlanması aşamasında, işveren temsilcilerine yönetmelik hakkında ne düşündükleri sorulmuştur. Torbalı Ticaret Odası yetkilileri ise işveren temsilcisi olarak görüş ve önerilerini bildirmiştir. Oda, kapasite raporlarının ilçe odaları tarafından verilebilmesi için İzmir'in tüm ilçe odaları ile bir araya gelerek çalışma yapmış ve lobicilik faaliyeti yürütmüştür. Oda, mecliste ana muhalefet partisi ve hükümete mensup milletvekillerini ziyaret ederek sanayicilerin yaşadığı sorunları hem yazılı, hem de sözlü olarak ifade etmektedir.

Oda, Türk Gıda Kodeksi Gıda Etiketleme ve Tüketicileri Bilgilendirme Yönetmeliği’ne göre eksik ve fazla gramaja ceza konusunda görüş bildirmiştir. 5977 Sayılı Biyogüvenlik Kanunu'nda yerini alan yönetmelik, eksik 
ve fazla gramaja 11.000 TL para cezası uygulaması yapmaktadır. Bu kapsamda kanunun yorumlanmasında hata olduğunu bildiren Torbalı Ticaret Odası, eksik gramajla satışın halkın aleyhine bir durum oluşturmasından dolayı desteklediğini, ancak fazla gramajın aleyhte bir durum oluşturmadığını tespit ederek yasama sürecinde meclise görüş bildirmiş ve etkili olmuştur. Bu çalışmalar sonucunda fazla gramaja para cezası kaldırılmıştır. Odaya kayıtlı üyelerin yaşadığı sorunlar iş hayatını kolaylaştırma yönünde 2011 tarih ve 6102 sayılı Ticaret Kanunu'nda belirtilerek kanun yapımına katkı sunulmuştur. Kanun düzenlemelerinde TOBB düzenlediği şura toplantılarında ilçe odalarından talep toplamaktadır. Torbalı Ticaret Odası dönem içerisinde sanayicilerin yaşadığı sorunları yasama sürecinde belirtmektedir. Sanayiciler genel olarak ticaret sicili, şirket sözleşmesi, genel yatırım ortamının kolaylaştırılması, teşvikler ve iş yaşamını kolaylaştırma ile ilgili düzenlemeler beklemekte olup bu beklentiler, kanun yapımında meclise bildirilmektedir. Torbalı Ticaret Odası 2003 tarihli 6331 sayılı kanun kapsamında iş yaşamını kolaylaştırmaya yönelik olarak çalışmalar yapmıştır. Oda, 2019 Torba Kanun düzenlemesinde de TOBB'a görüş bildirmiştir. Bu kapsamda oda, 2017 tarihli 7061 sayılı Bazı Vergi Kanunları ile Diğer Bazı Kanunlarda Değişiklik Yapılmasına Dair Kanun, 2018 tarihli 7103 sayılı Vergi Kanunu, 2012 tarihli 6356 sayılı Sendikalar ve Toplu İş Sözleşmesi Kanunu ve 2011 tarihli 635 sayılı Yükseköğretim Kurumlarının Araştırma ve Geliştirme Projelerinin Karşılanması Hakkında Kanun Hükmünde Kararname düzenlemesinde etkili olmuştur.

Torbalı Ticaret Odası, 2018 tarihli 7099 sayılı Yatırım Ortamının İyileştirilmesi Amacıyla Bazı Kanunlarda Değişiklik Yapılmasına Dair Kanun'un hazırlanışında görüş bildirmiştir. Bu kapsamda şirketlerin kuruluşunda daha önce noter tasdiki istenirken, kanun düzenlemesi sonrası noter tasdiki gerekmeksizin şirket kuruluşlarını tek noktadan ticaret odaları yapmaya başlamıştır. 2011 tarihli 6111 sayılı Bazı Alacakların Yeniden Yapılandırılması ile Sosyal Sigortalar ve Genel Sağlık Sigortası Kanunu ve Diğer Bazı Kanun ve Kanun Hükmünde Kararnamelerde Değişiklik Yapılması Hakkında Kanun ile birlikte getirilen istihdam teşviklerinden yararlanma konusunda yatırımcının yanında yer alarak kanun düzenlemelerinde söz sahibi olmuştur.

Oda, 2012 tarihli 3305 sayılı Yatırımlarda Devlet Yardımları Hakkında Bakanlar Kurulu Kararı'nın değişikliği hakkında çalışma yürütmektedir. Oda ayrıca Torbalı ilçesinin özel teşvik bölgesine alınması konusunu sürekli mecliste gündeme taşımaktadır. 1. sanayi teşviki bölgesinde yer alan Torbalı ilçesinde teşvik miktarı yeterli düzeyde değildir, coğrafi olarak ilçeye yakın olan Manisa ilindeki yatırımcılar 3. teşvik bölgesinde bulunduğundan İzmir'den çok daha cazip oranda teşvikler alabilmektedir. Hâlbuki Torbalı ilçesi Türkiye'de vergi hasılat oranında illerle yarışan düzeyde olmasına rağmen İzmir ilinin 1. teşvik bölgesinde bulunmasından dolayı Manisa kadar avantajlı konumda değildir. Sanayide teşvikler genel olarak KDV istisnası, gümrük vergisi muafiyeti, vergi indirimi, sigorta primi işveren hissesi desteği, gelir vergisi stopajı desteği, sigorta primi desteği, faiz desteği, yatırım yeri tahsisi, KDV iadesi gibi kalemlerden oluşmaktadır. Ancak Torbalı'daki sanayiciler İzmir ilinin 1. teşvik bölgesinde yer almasından dolayı sadece KDV istisnası, gümrük vergisi muafiyeti, yatırım yeri tahsisinden yararlanmaktadır. İlçedeki yatırımcılar vergi indiriminden yararlanma konusunda ise OSB dışında 15 yıl, OSB içinde 20 yıl teşvikten yararlanabilmektedir. Madencilik, demiryolu ve denizyolu yük taşımacılığı, savunma sanayi yatırımları, otomotiv, uzay sanayi, rüzgâr enerjisi üretimi için kanat, türbin ve jeneratör imalatı ve sanayi üretimine yönelik ar-ge projeleri öncelikli yatırım desteklerinin verildiği sektörlerdir. Bu tip yatırımların tamamında KDV istisnası, gümrük vergisi muafiyeti ve yatırım yeri tahsisi bulunmakla birlikte sigorta primi işveren hissesi desteği 7 yıldır. Vergi indirimi $\% 80$ ve yatırıma katkı oranı \%40’tır. Bu kapsamda Torbalı'da öncelikli yatırım alanlarının artması ve sektörlerin kazanacağı avantajlar konusunda sanayiciler oda tarafından bilgilendirilmektedir. Torbalı'da öncelikli yatırım alanlarında ihracat miktarının diğer ihracat kalemlerine göre yoğun olmadığ görülmektedir. İlçede 27 sektörde ihracat yapılmakta iken bunlardan sadece 3 sektör öncelikli yatırım alanı kapsamındadır. 2018 ihracat verilerine göre Torbalı'da gemi ve yat sanayide 451.337 dolar, savunma ve havacıllk sanayide 30.247 .390 dolar ve maden ve metal işlemeciliği sektöründe 10.926.319 dolarlık ihracat değerine ulaşılmıştır. İlçede uzay sanayi, savunma sanayi, otomotiv, yenilenebilir enerji ve yazılım gibi sektörlerin eksikliği hissedilmekte ve mevcut desteklemelerden bu alanlarda faaliyet gösteren firma bulunmadığından yararlanılamamaktadır.

\subsection{Torbalı İlçesi Ekonomik Göstergeleri ve Torbalı Ticaret Odası’nın Katkısı}

Torbalı Ticaret Odası, ilçe ekonomik durumunu özetleyen raporları çıkararak ilçe ekonomik göstergelerini toplayan, kamuoyu ile paylaşan ve hükümete aylık ekonomik tabloları rapor eden bir sivil toplum kuruluşudur. Oda, ilçeye ait ekonomik verilerin tespitinde Ege İhracatçı Birlikleri ve Ege Bölgesi Sanayi Odası ile ortak çalışmaktadır. Odaya kayıtlı 2513 üyenin 700'ü sanayici ve bunların 398'i ihracatçı olup kalan 2115'i iç pazara yönelik üretim yapmaktadır. Üretim yapan firmaların yoğunlaştığı bölgeler ise Yazıbaşı, Pancar, Subaşı ve Ayrancilar'dir. 
YILMAZ, Vedat ve ÇELIK EFŞAN, Nur - İlçelerin Yerel Kalkınmasında Sanayi ve Ticaret Odalarının Rolü: Torbalı Ticaret Odası Örneği

Tablo 2. 2017-2018 Yılları Torbalı İhracatı Sektörel Dağılımı ve İhracat Miktarları

\begin{tabular}{|c|c|c|}
\hline İHRACAT YAPILAN SEKTÖRLER & ABD \$ (2017) & ABD \$ (2018) \\
\hline Hazır Giyim ve Konfeksiyon & $22.823 .116,55$ & $26.478 .553,06$ \\
\hline Tekstil ve Hammaddeleri & $53.827 .979,07$ & $40.503 .961,71$ \\
\hline Deri ve Deri Mamulleri & $26.648 .889,53$ & 28.357.916,26 \\
\hline Halı & $34.048,33$ & $34.393,29$ \\
\hline Su Ürünleri ve Hayvancılık Mamulleri & $17.738 .138,34$ & $12.409 .244,03$ \\
\hline Findık ve Mamulleri & $761.162,15$ & $593.174,32$ \\
\hline Kuru Meyve ve Mamulleri & $14.644 .802,26$ & 15.172.605,08 \\
\hline Zeytin ve Zeytinyağ & $30.866 .450,07$ & $48.343 .438,24$ \\
\hline Yaş Meyve ve Sebze & $2.326 .903,98$ & $3.531 .842,40$ \\
\hline Meyve Sebze Mamulleri & $38.414 .950,44$ & $36.560 .258,83$ \\
\hline Süs Bitkileri ve Mamulleri & $461.821,06$ & $137.329,07$ \\
\hline Hububat, Bakliyat, Yağlı Tohumlar ve Mamulleri & $11.627 .711,18$ & $31.092 .988,67$ \\
\hline Tütün & $472.279 .819,98$ & 494.540.227,06 \\
\hline Elektrik - Elektronik & $12.098 .285,29$ & $14.987 .310,46$ \\
\hline Taşıt Araçları ve Yan Sanayi & $18.032 .067,41$ & $20.659 .181,90$ \\
\hline Gemi ve Yat Sanayi & $765.321,59$ & $451.337,15$ \\
\hline Kimyevi Maddeler ve Mamulleri & $58.760 .754,07$ & $66.994 .623,60$ \\
\hline Ağaç Mamulleri ve Orman Ürünleri & $95.557 .313,03$ & $105.260 .645,51$ \\
\hline Çimento Cam Seramik ve Toprak Ürünleri & $7.554 .387,44$ & $8.338 .364,35$ \\
\hline Demir ve Demir Dıı̧ı Metaller & $47.580 .426,60$ & $54.757 .843,01$ \\
\hline Çelik Sanayi & $10.991 .946,07$ & 13.387.499,08 \\
\hline Maden ve Metaller & $8.517 .115,70$ & $10.926 .319,77$ \\
\hline Diğer Sanayi Ürünleri & $1.306 .451,22$ & $2.884 .992,47$ \\
\hline Değerli Maden ve Mücevherat & 15,89 & 790,07 \\
\hline Makine ve Aksamları & $54.327 .960,31$ & $48.155 .796,32$ \\
\hline İklimlendirme Sanayi & $52.688 .213,31$ & $65.890 .676,24$ \\
\hline Savunma ve Havacıllk Sanayi & $28.011 .069,72$ & $30.247 .390,48$ \\
\hline Genel Toplam & 1.088.647.120,59 & $1.180 .698 .702,43$ \\
\hline
\end{tabular}

Kaynak: Torbalı Ticaret Odası yetkilileri ile yapılan görüşmede alınan verilerden elde edilerek hazırlanmıştır. 
2017 ile 2018 yılları Torbalı ihracatı sektörel dağılımı ve ihracat miktarlarını gösteren tablo 2 incelendiğinde, birçok alanda ihracatın yapıldığ 2017 ve 2018 yılında en fazla ihracatın tütün, en az ihracatın ise değerli maden ve mücevherat sektöründe gerçekleştirildiği görülmektedir.

Tablo 3. Torbalı İlçesinin 2017-2018 Yıllarındaki Diğer İzmir İlçeleri Arasındaki İhracat Rakamları Sıralaması

\begin{tabular}{|c|c|c|c|c|}
\hline $\begin{array}{l}\text { İHRACATTAKİ } \\
\text { SIRASI }\end{array}$ & İLÇE & 2017 (ABD \$) & $2018(\mathrm{ABD} \$)$ & $\begin{array}{l}\text { GENEL TOPLAM } \\
\text { (ABD \$) }\end{array}$ \\
\hline 1. & KONAK & 2.034.807.282 & 2.281.413.671 & 4.316.220.953 \\
\hline 2. & ÇİĞLİ & 1.535 .254 .932 & 1.684 .048 .381 & 3.219 .303 .314 \\
\hline 3. & KEMALPAŞA & 1.098 .692 .899 & 1.243 .953 .024 & 2.342 .645 .924 \\
\hline 4 & TORBALI & 1.090.557.152 & 1.187 .522 .308 & 2.278.079.460 \\
\hline 5. & BORNOVA & 970.687 .132 & 1.076 .303 .229 & 2.046.990.361 \\
\hline 6. & ALİAĞA & 801.098 .251 & 828.587 .228 & 1.629.685.480 \\
\hline 7. & BAYRAKLI & 345.094 .484 & 348.612 .840 & 693.707 .324 \\
\hline 8. & MENEMEN & 218.544 .161 & 255.467 .844 & 474.012 .005 \\
\hline 9. & GAZIEMIR & 217.568 .940 & 216.087 .885 & 433.656 .826 \\
\hline 10. & BUCA & 132.888 .447 & 161.959 .264 & 294.847 .712 \\
\hline 11. & TİRE & 113.294 .538 & 137.074 .315 & 250.368 .854 \\
\hline 12. & MENDERES & 96.938 .037 & 126.055 .564 & 222.993 .602 \\
\hline 13. & SEFERİHISAR & 103.328 .254 & 90.323 .283 & 193.651 .537 \\
\hline 14. & KARŞIYAKA & 74.252 .442 & 83.578 .411 & 157.830 .853 \\
\hline 15. & BERGAMA & 27.411 .548 & 85.048 .183 & 112.459 .732 \\
\hline 16. & KARABAĞLAR & 47.617 .938 & 62.890 .747 & 110.508 .686 \\
\hline 17. & URLA & 35.086 .170 & 37.562 .059 & 72.648 .230 \\
\hline 18. & ÖDEMİş & 24.862 .373 & 33.448 .545 & 58.310 .919 \\
\hline 19. & BALÇOVA & 15.868 .830 & 19.794 .451 & 35.663 .282 \\
\hline 20. & GÜZELBAHÇE & 13.479 .529 & 15.417 .343 & 28.896 .872 \\
\hline 21. & BEYDAĞ & 7.809 .678 & 8.802 .385 & 16.612 .063 \\
\hline 22. & KINIK & 7.888 .753 & 6.207 .130 & 14.095 .883 \\
\hline 23. & SELÇUK & 4.617.219 & 5.630 .255 & 10.247 .475 \\
\hline 24. & MERKEZ & 4.079 .174 & 5.407 .905 & 9.487 .079 \\
\hline 25. & NARLIDERE & 5.502 .761 & 2.172 .381 & 7.675 .142 \\
\hline 26. & DİKİLİ & 2.341 .027 & 3.077 .554 & 5.418 .582 \\
\hline 27. & FOÇA & 1.098 .127 & 1.264 .067 & 2.362 .194 \\
\hline
\end{tabular}


YILMAZ, Vedat ve ÇELIKK EFŞAN, Nur - İlçelerin Yerel Kalkınmasında Sanayi ve Ticaret Odalarının Rolü: Torbalı Ticaret Odası Örneği

\begin{tabular}{|c|c|c|c|c|}
\hline $\mathbf{2 8 .}$ & ÇEŞME & 1.216 .848 & 1.081 .949 & 2.298 .798 \\
\hline $\mathbf{2 9}$. & BAYINDIR & 240.474 & 587.353 & 827.827 \\
\hline $\mathbf{3 0 .}$ & KİRAZ & 108.219 & 128.825 & 237.044 \\
\hline \multicolumn{2}{|c|}{ GENEL TOPLAM } & $\mathbf{9 . 0 3 5 . 9 9 0 . 1 1 8}$ & $\mathbf{1 0 . 0 1 3 . 4 6 1 . 9 8 0}$ & $\mathbf{1 9 . 0 4 9 . 4 5 2 . 0 9 8}$ \\
\hline
\end{tabular}

Kaynak: Ege İhracatçı Birlikleri Basın Müşaviri ile yapılan görüşmeden elde edilen verilere göre hazırlanmıştır.

Torbalı ilçesinin 2017 ile 2018 yılları arası İzmir ilinin diğer ilçeleri arasındaki ihracat rakamları sıralamasını gösteren tablo incelendiğinde; İzmir ilinin 30 ilçesi olduğu ve ilçeleri arasında en fazla ihracatın Konak ilçesinden, en az ihracatın Kiraz ilçesinde gerçekleştiği, Torbalı ilçesinin ise belirtilen ilçeler arasında 4. sırada yer aldığı görülmektedir. Verilen bilgiler ışığında Torbalı ilçesinde yapılan ihracatın hem ilçe açısından hem de il açısından genel olarak da ülke açısından önemli bir yerinin olduğu söylenebilir.

Tablo 4. 12018 Yılı Torbalı İlçesinden İhracat Yapılan Ülkeler ve İhracat Miktarları

\begin{tabular}{|c|c|c|c|c|c|}
\hline Sira & $\begin{array}{c}\text { İhracat Yapılan } \\
\text { Ülke }\end{array}$ & $\begin{array}{l}\text { İhracat Miktarı } \\
\text { (Milyon \$) }\end{array}$ & Sira & İhracat Yapılan Ülke & $\begin{array}{l}\text { İhracat Miktarı } \\
\quad \text { (Milyon \$) }\end{array}$ \\
\hline 1 & $\mathrm{ABD}$ & 125 & 13 & Hindistan & 28 \\
\hline 2 & Almanya & 68 & 14 & Birleşik Arap Emirlikleri & 23 \\
\hline 3 & İngiltere & 65 & 15 & Misir & 20 \\
\hline 4 & Fransa & 59 & 16 & İspanya & 19 \\
\hline 5 & Suudi Arabistan & 56 & 17 & Romanya & 18 \\
\hline 6 & İran & 49 & 18 & Kuveyt & 17 \\
\hline 7 & İsrail & 47 & 19 & Rusya & 16 \\
\hline 8 & Hollanda & 46 & 20 & Brezilya & 15 \\
\hline 9 & Belçika & 45 & 21 & Polonya & 14 \\
\hline 10 & Fas & 40 & 22 & Meksika & 13 \\
\hline 11 & Irak & 37 & 23 & Filistin & 12 \\
\hline 12 & İtalya & 29 & 24 & Yunanistan & 11 \\
\hline
\end{tabular}

Kaynak: Ege İhracatçı Birlikleri Basın Müşaviri ile yapılan görüşmede elde edilen verilerden hazırlanmıştır.

2018 yılı Torbalı ilçesinden ihracat yapılan ülkeler ve ihracat miktarlarını gösteren tablo incelendiğinde Torbalı ilçesinden en çok ihracat yapılan 24 ülkedenen fazla ihracatın Amerika Birleşik Devleti'ne, en az ihracatın ise Yunanistan'a yapıldı̆̆ı görülmektedir. Verilen bilgiler ışı̆̆ında Torbalı ilçesinde yapılan ihracatın hem ilçe ekonomisine hem de ülke ekonomisine önemli katkılar sağladığı görülmektedir. 


\section{SONUÇ}

Dünyada 1980'lerden itibaren enformasyon ve bilgi teknolojilerinde yaşanan gelişmeler ülkeler arası ekonomik rekabeti arttırmıştır. Haberleşme ağının da gelişmiş olduğu bu dönemde hızla küreselleşen dünya devletleri arasındaki ekonomik gelişme farklılıkları aynı ülke içerisinde farklı bölgelerde de ekonomik gelişmişlik farkları olarak tezahür etmiştir. Buna istinaden ülkeler arasında küresel ekonomik rekabetin yaşandığı bu dönemde ulusal ekonominin güçlenmesi için politikalar ve stratejiler üretilmiş, politikalarda başarı için yerel aktörler devreye sokulmuştur. Yerel ekonomik kalkınmanın ulusal kalkınmayı oluşturan temel bileşen olması dolayısıyla yerelde girişimciliğin desteklenmesi ve koordine edilmesi gerekmektedir. Yerel ekonomik kalkınmanın sağlanması ve bölge yatırımlarının organize edilmesinde yerel ekonomiye yön veren ticaret ve sanayi odaları; il ve ilçelerde endüstriyel üretimi arttıran, iç ve diş ticaret yelpazesini geliştiren, yerel girişimciye pazar araştırması yapan, sektör çeşitliliği ve sektörel üretim hacmini genişleten, devlet destekleri konusunda girişimciyi etkileyerek yerel istihdamı geliştiren kuruluşlar olarak hizmet etmektedir. Bu doğrultuda çalışmanın ana eksenini oluşturan Torbalı Ticaret Odası'nın faaliyetlerinin Torbalı ilçesinin yerel kalkınmasındaki etkisi araştırılmış olup çalışma sonucunda şu bulgulara ulaşılmıştır;

Torbali Ticaret Odası'nın, 2011'de İzmir iline bağlı 30 ilçe arasında ilk kez KOSGEB Temsilciliği kurarak 2000'i aşkın üyesini KOBİ destekleri konusunda bilgilendirdiği ve desteklerden yararlandırdığı, ilçede yeni kurulacak işletmelere yön verdiği ve ilçe istihdam düzeyine katk1 sunduğu tespit edilmiştir. Odanın bünyesinde kayıtlı KOBİ'lere devlet teşvikleri konusunda bilgilendirme yaptığı, bu bakımdan ilçedeki ekonomik ilerlemenin öncüsü olarak kabul edildiği, oda üyelerine yönelik verdiği tüm hizmetlerle, ilçedeki yerel ekonomik kalkınmanın yön belirleyicisi ve sağlayıcısı olduğu tespit edilmiştir. Yine odanın ilçedeki işsizlikle mücadele ve yurt dışı ticaret odaları ve fuarcılık hizmetlerine yönelikönemli faaliyetlerde bulunduğu ortaya çıkmış olup oda faaliyetlerinin ilçedeki sanayi kuruluşlarının, yerel yönetimlerin ve vatandaşların sorunlarının çözümüne yönelik gerçekleştirildiği, odanın ilçede yerel ekonomik kalkınmayı organize eden bir kuruluş olarak bir sivil toplum kuruluşundan beklenenden daha fazla performans gösterdiği, ilçenin ulusal ve uluslararas1 basında tanıtımı ve ilçedeki ihracat rakamlarının yükselmesinde önemli düzeyde katkısının olduğu ve bu sayede odanın ekonomik anlamda hem ilçe hem de ülke ekonomisine önemli katkılar sağladığı bulgularına ulaşılmıştır.

Torbalı Ticaret Odası'nın; kendisine bağlı 398 ihracatçı üyesi, Ege İhracatçı Birlikleri'ne de kayıtlıdır. İlçeden dünyanın 100'ü aşkın ülkesine ihracat yapılmaktadır.2018 yılı oda verilerine göre ihracatta en önemli ülkeler; ABD, Almanya ve İngiltere olup, toplam ihracat rakamı 1.180.698.702 dolardır. İhracatta en önemli kalemlerise; gıda, iklimlendirme, demir ve demir dışı metaller, tekstil, tütün, mobilya ve kimya sanayidir. İhracat değeri ve hacmi en büyük olan sektörler $\% 41,8$ pay ve 494 milyon dolar ile tütün, $\% 8,9$ pay ve 105 milyon dolar ile mobilya ve \%5,6 pay ve 67 milyon dolar ile kimya sektörüdür. İhracatçı üye sayısı bakımından gıda, iklimlendirme, makine, mobilya, demir-çelik, mermer ve doğaltaş sektörü firmalarının diğer sektörlere sayıca üstünlüğü bulunmaktadır. Yine 2018 yılı oda verilerine göre Torbalı, İzmir'in 30 ilçesi arasında \%12 ihracat oranına sahiptir. İhracat rakamları bakımından Konak, Çiğli ve Kemalpaşa'dan sonra gelen ilçe 26 ilçeyi gerisinde bırakmıştır.

İlçede endüstriyel üretimde katma değeri yüksek olan yazılım, havacılık-uzay sanayi, otomotiv ve yenilenebilir enerji sektörlerinin payının arttırılması, bu konuda yatırımcıları teşvik konusunda tanıtımların sürdürülmesi, uzun vadede elektronik ticaret uygulamasının üyeler arasında yaygınlaştırılması ve Torbalı Ticaret Odası'nındiğer odalarla işbirliği içerisinde çalışması halinde hem ilçe hem de ülke ekonomisine daha fazla katkının sağlanacağı düşünülmektedir. 


\section{KAYNAKÇA}

5174 sayılı Türkiye Odalar ve Borsalar Birliği ile Odalar ve Borsalar Kanunu (01.06.2004 tarih ve 25479 sayılı Resmi Gazete). http://www.mevzuat.gov.tr/MevzuatMetin/1.5.5174.pdf (Erişim Tarihi: 7.06.2019).

ATMACA, Yıldız (2018), "Yerel Kalkınma Politikaları ve Amaçları Doğrultusunda Kalkınma Ajansları ve Uygulanabilirliği”, II. Uluslararası Ekonomi, Siyaset ve Yönetim Sempozyumu (ISEPA'18) Bildiriler Kitabı (Ed. Yılmaz Demirhan, Seyfettin Aslan, Müslüm Kayacı, Ömer Taylan), Dicle Üniversitesi Yayını, Diyarbakır, ss.427-436.

AYDEMİR, Cahit ve GÜNEŞ, Hüseyin Haşimi (2006), "Merkantilizmin Ortaya Çıkışı", Elektronik Sosyal Bilimler Dergisi, S.5(15), ss.136-158.

BOZDOĞAN, Mine (2014), Türkiye'de Bölgesel Kalkınma ve Teşvik Politikaları, Nobel Yayınları, Ankara.

ÇETIN, Murat (2007), "Yerel Ekonomik Kalkınma Yaklaşımı ve Uluslararası Organizasyonlar", Yönetim ve Ekonomi Dergisi, S.14(1), ss.153-170.

DEVİREN, Vatansever Nursen ve YILDIZ, Onur (2014), "Bölgesel Kalkınma Teorileri ve Yeni Bölgeselcilik Yaklaşımının Türkiye’deki Bölgesel Kalkınma Politikalarına Etkileri", Akademik Bakış Dergisi, S.44, ss.1-35.

GÜRLER HAZMAN, Gülsüm (2011), Türkiye'de Belediyeler ve Yerel Ekonomik Kalkınmaya Katkıları, Seçkin Yayıncılık, Ankara.

HELMSING, Bert (2005), Local Economic Development in Africa: Introducing The Issues Enterprises, Communitiesand Local Government, Shaker Publisher, Maastricht.

KAYA, Erol (2001), Kent Yönetiminde Yeni Yaklaşım: Yerel Kalkınma Yönetimi, Beta Yayınları, İstanbul, 2.Bask1.

KONGOLO, Mukole (2010), "Job Creation Versus Job Sheddingand Live Role of Smalland Medium Sized Enterprises in Economic Development", African Journal of Business Management, S.4(11), ss.22882295.

LANDSBERG, Johann, MEYER, Danie F. ve MEYER, Natanya (2016), "The Roles of Business Chambers in Local Economic Development: The Perceptions of Business Chambers in The Vaal Triangle Region", International Journal of Business And Management Studıes, S.8(2), ss.66-83.

LEIGH, Nancey Green ve BLAKELY, Edward J. (2013), Planning Local Economic Development: Theoryand Practice, SAGE Publications, California, 5.Bask1.

LEIGH, Nancey Green ve BLAKELY, Edward J. (2017), Planning Local Economic Development: Theoryand Practice, SAGE Publications, California, 6.Bask1.

RODRIGUEZ-POSE, Andres (2001), The Role of The ILO in Implementing Local Economic Development Strategies in a Globalized World, LSE Publisher, London.

ŞANLI, Bahar Fatma (2004), "Küreselleşme ve Ekonomik Entegrasyonlar", Doğu Anadolu Bölgesi Araştırmaları Dergisi, S.1, ss.160-166.

T. C. TORBALI BELEDIYE BAŞKANLIĞI (2014), Torbalı Belediyesi 2015-2019 Dönemi Stratejik Planı, Torbalı Belediye Başkanlığı Yayını, İzmir.

TOBB - TÜRKIYE ODALAR VE BORSALAR BİRLİĞİ (2017), Türkiye Odalar ve Borsalar Birliği Faaliyet Raporu, TOBB Yayını, Ankara.

TROUSDALE, William (2005), Promoting Local Economic Development Through Strategic Planning Volume:5 Trainer's Guide, United Nations Human Settlements Programme (UN-HABITAT) Published, Nairobi - Kenya. http://mirror.unhabitat.org/downloads/docs/LEDVol5English.pdf (Erişim Tarihi: 07.06.2019).

ZYL, Van (1994), Development Management: A Training Perspective, Halfway House, DBSA. 